\title{
Negative trade-off between changes in vegetation water use and infiltration recovery after reforesting degraded pasture land in the Nepalese Lesser Himalaya
}

\author{
C. P. Ghimire ${ }^{1}$, L. A. Bruijnzeel ${ }^{2}$, M. W. Lubczynski ${ }^{1}$, and M. Bonell ${ }^{3, \dagger}$ \\ ${ }^{1}$ Faculty of Geo-Information Science and Earth Observation (ITC), University of Twente, Enschede, the Netherlands \\ ${ }^{2}$ Critical Zone Hydrology Group, Faculty of Earth and Life Sciences, VU University, Amsterdam, the Netherlands \\ ${ }^{3}$ The Centre for Water Law, Policy and Science under the auspices of Unesco, The Peters Building, University of Dundee, \\ Dundee, DD14HN, Scotland, UK \\ $\dagger$ deceased
}

Correspondence to: C. P. Ghimire (c_ghimire@yahoo.com)

Received: 10 March 2014 - Published in Hydrol. Earth Syst. Sci. Discuss.: 25 March 2014

Revised: 2 September 2014 - Accepted: 13 September 2014 - Published: 9 December 2014

\begin{abstract}
This work investigates the trade-off between increases in vegetation water use and rain water infiltration afforded by soil improvement after reforesting severely degraded grassland in the Lesser Himalaya of central Nepal. The hillslope hydrological functioning (surface and subsurface soil hydraulic conductivities and overland flow generation) and the evapotranspiration (rainfall interception and transpiration) of the following contrasting vegetation types were quantified and examined in detail: (i) a nearly undisturbed, natural broadleaved forest; (ii) a 25-year-old, intensively-used pine plantation; and (iii) a highly degraded pasture. Planting pines increased vegetation water use relative to the pasture and natural forest situation by 355 and $55 \mathrm{~mm}$ year $^{-1}$, respectively. On balance, the limited amount of extra infiltration afforded by the pine plantation relative to the pasture (only $90 \mathrm{~mm}_{\text {year }}{ }^{-1}$ due to continued soil degradation associated with regular harvesting of litter and understory vegetation in the plantation) proved insufficient to compensate the higher water use of the pines. As such, observed declines in dry season flows in the study area are thought to mainly reflect the higher water use of the pines although the effect could be moderated by better forest and soil management promoting infiltration. In contrast, a comparison of the water use of the natural forest and degraded pasture suggests that replacing the latter by (mature) broadleaved forest would (ultimately) have a near-neutral effect on dry season flows as the approximate gains in infiltration and evaporative losses
\end{abstract}

were very similar (ca. $300 \mathrm{~mm}_{\text {year }}{ }^{-1}$ each). The results of the present study underscore the need for proper forest management for optimum hydrological functioning as well as the importance of protecting the remaining natural forests in the region.

\section{Introduction}

The traditional view of forest hydrological functioning, in which wet season rainfall is readily absorbed and stored for subsequent gradual release during the dry season, has often been likened to a "sponge" (Hamilton and King, 1983). Although the forest sponge effect had been the subject of debate before (cf. reviews of older literature by Andréassian, 2004; Bruijnzeel, 2004; Galudra and Sirait, 2009), the concept came under severe scrutiny in the early 1980s when Bosch and Hewlett (1982) reviewed the results from nearly 100 paired catchment experiments around the globe. They concluded that "no experiments in deliberately reducing vegetation cover caused reductions in water yield, nor have any deliberate increases in cover caused increases in yield". As such, the removal of a dense forest cover was seen to lead to higher streamflow totals, and reforestation of open lands to a decline in overall streamflow. These initial results were confirmed by several subsequent reviews, both for the (warm) temperate zone (Stednick, 1996; Brown et al., 2005; Jackson 
et al., 2005) and the humid tropics (Bruijnzeel, 1990; Grip et al., 2005; Scott et al., 2005). Whilst the majority of experiments concerned small catchments $\left(<2 \mathrm{~km}^{2}\right)$, comparable results of increased water yield following forest removal and reduced flows following forestation were also obtained for much larger river basins (1100-175000 km²; Trimble et al., 1987; Madduma Bandara, 1997; Costa et al., 2003; Zhou et al., 2010). The fact that the bulk of the change in streamflow associated with such experiments was observed during conditions of baseflow (Bosch and Hewlett, 1982; Bruijnzeel, 1989; Farley et al., 2005) at first sight contradicted the reality of the forest sponge concept, and its very existence became questioned (Hamilton and King, 1983; Calder, 2005). Indeed, since the early reviews of Bosch and Hewlett (1982) and Hamilton and King (1983), many have emphasised the more "negative" aspects of forests, such as their high water use or inability to prevent extreme flooding (e.g. Calder, 2005; FAO-CIFOR, 2005; Jackson et al., 2005; Kaimowitz, 2005) rather than focus on the positive functions of a good forest cover, including the marked reduction of surface erosion and shallow landslip occurrence (Sidle et al., 2006), improved water quality (Bruijnzeel, 2004; Wohl et al., 2012), moderation of all but the largest peak flows (Roa-García et al., 2011; Ogden et al., 2013) or carbon sequestration (Farley et al., 2005; Malmer et al., 2010).

At the same time, there is ample evidence of severe and widespread soil degradation after tropical forest conversion to unsustainable forms of land use (e.g. overgrazed pastures, subsistence cropping on steep slopes without adequate soil conservation measures, etc.; Oldeman et al., 1991; Bai et al., 2008). In addition, the area occupied by impervious surfaces such as roads, trails, built-up areas and yards is also on the increase (Ziegler and Giambelluca, 1997; Rijsdijk et al., 2007; Sidle and Ziegler, 2012). This is often accompanied by strongly increased stormflow volumes during times of rainfall (Bruijnzeel and Bremmer, 1989; Fritsch, 1993; Chandler and Walter, 1998; Zhou et al., 2002; Ziegler et al., 2004; Ziegler et al., 2007) and shortages of water during extended dry periods (Bartarya, 1989; Madduma Bandara, 1997; Bruijnzeel, 2004; Tiwari et al., 2011). Such changes in streamflow regime effectively reflect the loss of the former forest sponge (cf. Roa-García et al., 2011; Krishnaswamy et al., 2012; Ogden et al., 2013) through critically reduced replenishment of soil water and groundwater reserves due to lost surface infiltration opportunities, despite the fact that the lower water use of the post-forest vegetation should have produced higher streamflows throughout the year (Bruijnzeel, 1986, 1989).

Reforestation of degraded land in the tropics is often conducted in the expectation that disturbed streamflow regimes (commonly referred to as the "too little-too much syndrome": Bartarya, 1989; Schreier et al., 2006) will be restored by the increased rainfall absorption afforded by soil improvement after tree planting (Scott et al., 2005; cf. Ilstedt et al., 2007). At the same time, the water use of fast- growing tree plantations tends to be (much) higher than that of the degraded vegetation they typically replace - particularly where the trees have access to groundwater (Calder, 1992; Kallarackal and Somen, 1997). Furthermore, major improvements in the (near-)surface infiltration capacity of severely degraded soils, after tree planting may well take several decades of undisturbed forest development to fully materialise (Gilmour et al., 1987; Scott et al., 2005; Bonell et al., 2010). As such, reforesting degraded pasture or shrub land may well cause already diminished dry season flows to become reduced even further, depending on the net balance between increases in soil water reserves through improved infiltration versus decreases caused by the higher plant water uptake (the so-called "infiltration trade-off" hypothesis; Bruijnzeel, 1986, 1989).

Although the overwhelming majority of paired catchment experiments have shown major decreases in baseflow volumes, after the establishment of a tree cover on non-forested land (Farley et al., 2005) this does not disprove the possibility of enhanced dry season flows after reforestation at the small catchment scale. As pointed out by Bruijnzeel (2004) and Malmer et al. (2010), only three out of the 26 paired catchment studies of the hydrological impacts of reforestation reviewed by Jackson et al. (2005) and Farley et al. (2005) were located in the tropics (where soil degradation tends to be more acute; Oldeman et al., 1991; Bai et al., 2008) whereas none of the experiments represented degraded soil conditions. In other words, no positive effects of reforestation on soil water intake capacity could manifest and the observed reductions in water yield simply reflected the higher water use of the trees compared to the grasses and scrubs they replaced (cf. Trimble et al., 1987; Waterloo et al., 1999; Scott and Prinsloo, 2008).

Nevertheless, although direct evidence for the infiltration trade-off hypothesis seemed to be lacking until recently (see below), several hillslope-scale or small-basin studies of the hydrological impacts of reforesting severely degraded land (discussed in some detail by Scott et al., 2005) observed reductions in stormflow volumes that were likely to exceed the estimated corresponding increases in vegetation water use (cf. Zhang et al., 2004; Sun et al., 2006). Unfortunately, as the catchments involved in these experiments were either too small or leaky to sustain perennial streamflow, the expected net positive effect of forestation on dry season flows could not be ascertained in these cases (Scott et al., 2005; cf. Chandler, 2006). However, recently published concurrent reductions in stormflow response to rainfall, and positive trends in baseflow over time since reforesting severely degraded land in southern China (Zhou et al., 2010) and South Korea (Choi and Kim, 2013), or along a forest degradation-recovery gradient in the Western Ghats of India (Krishnaswamy et al., 2012,2013 ) are highly suggestive of a net positive outcome of the infiltration trade-off mechanism.

A related aspect concerns the vexed question whether or to what extent (or at what scale) reforestation may have a 
positive influence on the amount of precipitation received. Although it is clear that tree planting at the local scale $(<50 \mathrm{~km})$ cannot be expected to have such an effect (Harding, 1992), claims of a positive effect of large-scale forestation on rainfall generation are becoming more frequent (see Ellison et al., 2011, for an in-depth discussion). At the same time, re-establishing forest cover over an area of ca. $67000 \mathrm{~km}^{2}$ of wasteland over a period of 50 years in southern China did not produce any change in rainfall (Zhou et al., 2010). Furthermore, in a particularly comprehensive observational study of Amazonian rainfall and its dependence on vegetation (Angelini et al., 2011), isotopic analysis showed the precipitation to originate mostly from largescale weather systems linking the interior region to the ocean and precipitation to derive only very partly from local evaporation. Nevertheless, there are some indications that largescale deforestation may negatively affect rainfall during the transition from wet season to dry season in mainland Southeast Asia (Kanae et al., 2001; cf. Kumagai et al., 2013) and therefore it cannot be excluded that the reverse case also applies (Spracklen et al., 2012). All in all, in the absence of strong empirical evidence of a major effect of tree plantation on rainfall, it is difficult to take into account any possibly positive influence at this stage.

The Middle Mountain zone of the Nepalese and Indian Himalayas provides another case in point regarding the need to restore diminished dry season flows. The rivers originating in this densely populated part of the mountain range (Singh et al., 1984; Hrabovszky and Miyan, 1987) are mostly rainfed and thus do not benefit from increased water yields from melting glaciers under a changing climate scenario (Bookhagen and Burbank, 2010; Andermann et al., 2012; Immerzeel et al., 2013). Land surface degradation in the zone has often progressed to a point where rainfall infiltration has become seriously impaired and overland flow is rampant (Bruijnzeel and Bremmer, 1989; Gerrard and Gardner, 2002; cf. Ghimire et al., 2013), with reduced dry season flows as the result (Bartarya, 1989; Tiwari et al., 2011; Tyagi et al., 2013). Partly in response to the latter problem, some 23000 ha of severely degraded pastures and shrublands in the Middle Mountain zone of central Nepal were planted to fast-growing coniferous tree species (mainly Pinus roxburghii and P. patula) between 1980 and 2000 (District Forest Offices, Kabhre and Sindhupalchok, unpublished data, 2010). However, villagers and farmers in central Nepal have expressed serious concerns about diminishing spring discharges and dry season flows following the large-scale planting of the pines (República, 2012). Such considerations assume added importance under the strongly seasonal climatic conditions prevailing in the Middle Mountain zone where $\sim 80 \%$ of the annual rainfall falls during the main monsoon (June-September; Merz, 2004; Bookhagen and Burbank, 2010) and where water during the dry season is already at a premium (Merz et al., 2003).

There is a dearth of sound experiments in the Himalayan region to ascertain the hydrological effects of land use change (reviewed by Bruijnzeel and Bremmer, 1989; Negi, 2002) and indeed for the (sub)tropics in general with respect to the extent to which reforestation of degraded land can improve or even restore diminished dry season flows (Scott et al., 2005; Zhou et al., 2010; Krishnaswamy et al., 2013; Choi and Kim, 2013). In view of the difficulty of identifying catchments with a single dominant land cover type (e.g. forest or grassland) as well as being sufficiently large to support perennial flows (required for the evaluation of changes in baseflows during the extended dry season) in this rugged and spatially highly variable terrain (Maharjan, 1991; Merz, 2004; Bookhagen and Burbank, 2006), the present study opted for the "space for time substitution approach" in which experimental plots with contrasting land-cover types were studied in terms of their hydrological processes and taking the infiltration trade-off hypothesis as a starting point. Thus, the primary objective of the present study was to investigate the trade-offs between the changes in water use going from a severely degraded pasture to a mature coniferous tree plantation or well-developed broadleaved forest on the one hand, and the concurrent increases in soil water reserves afforded by improved rainfall infiltration after plantation or forest maturation on the other in a typically Middle Mountain zone setting in central Nepal. Total vegetation water use (evapotranspiration, ET), overland flow production and fieldsaturated soil hydraulic conductivity profiles with depth were determined in a little disturbed natural broad-leaved forest, a highly degraded pasture, and in a mature 25 -year-old planted pine forest near Dhulikhel. The resulting data were used to address the central question: can reforestation of severely degraded hillslopes in the heavily populated Nepalese Middle Mountain zone restore diminished dry season flows upon plantation maturation?

\section{Methods}

\subsection{Site description}

The Middle Mountain zone or Lesser Himalaya, which is situated between $\sim 800$ and $\sim 2400 \mathrm{~m}$ above mean sea level (a.m.s.l.) and which occupies about $30 \%$ of Nepal, is home to ca. $45 \%$ of the country's population (based on the 2011 population census; http://cbs.gov.np/). The zone is characterised by a complex geology which has resulted in equally complex topography, soil and vegetation patterns (Dobremez, 1976). The geology of the central Nepalese Middle Mountains consists chiefly of phyllites, schists and quartzites (Stocklin and Bhattarai, 1977). Depending on elevation, the climate is humid subtropical to warm temperate and strongly seasonal, with most of the rain falling between June and September. Rainfall varies with elevation and exposure to the prevailing monsoonal air masses (Merz, 2004; cf. Bookhagen and Burbank, 2006). Between 1000 and $2000 \mathrm{~m}$ a.m.s.l. the natural vegetation consists of a largely evergreen mixed 
broadleaved forest dominated by Schima wallichii and various chestnuts and oaks (Castanopsis spp., Quercus spp.), with Rhododendron arboreum as their main associate above ca. $1500 \mathrm{~m}$ a.m.s.l. Due to the prevailing population pressure, much of this species-rich forest has disappeared $(<10 \%$ remaining), except on slopes that are too steep for agricultural activity (Dobremez, 1976; Merz, 2004).

The present study was conducted in the Jikhu Khola catchment (JKC) (Fig. 1). The $111.4 \mathrm{~km}^{2} \mathrm{JKC}\left(27^{\circ} 35^{\prime}-27^{\circ} 41^{\prime} \mathrm{N}\right.$, $\left.85^{\circ} 32^{\prime}-85^{\circ} 41^{\prime} \mathrm{E}\right)$ is situated approximately $45 \mathrm{~km}$ east of Kathmandu (the capital of Nepal) along the Araniko Highway in the Kabhre District between 796 and 2019 m a.m.s.l. The general aspect of the catchment is southeast and the topography ranges from flat valleys to steep upland slopes (Maharjan, 1991). The geology consists of sedimentary rocks affected by various degrees of metamorphism and includes phyllites, quartzites, and various schists (Nakarmi, 2000). In general, soils in the upper half of the JKC are Cambisols (FAO, 2007) of loamy texture and moderately well to rapidly drained (Maharjan, 1991).

The climate of the JKC is largely humid subtropical, grading to warm temperate around $2000 \mathrm{~m}$ a.m.s.l. Mean ( \pm SD, standard deviation) annual rainfall measured at midelevation (1560 ma.m.s.l.) for the period 1993-1998 was $1487( \pm 155) \mathrm{mm}$ (Merz, 2004). The main seasons are the rainy season (monsoon; June-September), the post-monsoon (October-November), winter (December-February), and the pre-monsoon (March-May). During the monsoon about $80 \%$ of the total annual precipitation falls. In general, July is the wettest month with about $27 \%$ of the annual rainfall. The driest months are November-February, each accounting for about $1 \%$ of the annual rainfall (Merz, 2004). About 40$50 \%$ of monsoon rainfall occurs as small showers $(<5 \mathrm{~mm})$ while larger storms $(>30 \mathrm{~mm}$ ) are comparatively infrequent $(<8 \%)$. Maximum rainfall intensities are in the order of $75-$ $85 \mathrm{~mm} \mathrm{~h}^{-1}$ (based on 5-min observations) but median values are low at $2-2.5 \mathrm{~mm} \mathrm{~h}^{-1}$ (Ghimire et al., 2012). Average monthly temperatures as measured at $1560 \mathrm{~m}$ a.m.s.l. range from $7.7^{\circ} \mathrm{C}$ in January to $22.6^{\circ} \mathrm{C}$ in June while the average monthly relative humidity varies from $55 \%$ in March to $95 \%$ in September. Strong winds are common during thunderstorms before the onset of the main monsoon, but these are momentary and the average monthly wind speeds are always less than $2 \mathrm{~m} \mathrm{~s}^{-1}$ and show only slight seasonal variation. Annual reference evaporation $\mathrm{ET}_{0}$ (Allen et al., 1998) for the period 1993-2000 was $1170 \mathrm{~mm}$ (Merz, 2004). Vegetation cover in the catchment consists of $\sim 30 \%$ forest (both natural and planted), $7 \%$ shrubland and $6 \%$ grassland, with the remaining $57 \%$ largely under agriculture (Merz, 2004). The JKC was subjected to active reforestation until 2004 as part of the Nepal-Australia Forestry Project (NAFP).

We measured vegetation water use (wet- and dry-canopy evaporation), overland flow and saturated soil hydraulic conductivity $\left(K_{\mathrm{fs}}\right)$ in natural forest, degraded pasture and planted forest. The land use at the respective research sites can be characterised as follows:

Natural Forest: this site (elevation 1500 m a.m.s.l., northwest exposure, average slope angle $24^{\circ}$ ) consisted of dense, largely evergreen forest facing little anthropogenic pressure. The $14.0 \pm 2.2 \mathrm{~m}$ high forest had a well-developed understory and litter layer with visual evidence of soil faunal activity in the form of a high carbon content and numerous near-surface macropores. Tree density in the $50 \mathrm{~m} \times 50 \mathrm{~m}$ plot as measured in May 2011 was 1869 trees ha $^{-1}$, whereas the average diameter at breast height $(\mathrm{DBH})$ for trees with $\mathrm{DBH} \geq 5 \mathrm{~cm}$ was $13.6 \pm 4.4 \mathrm{~cm}$ and the corresponding basal area $27.1 \mathrm{~m}^{2} \mathrm{ha}^{-1}$. The forest was floristically diverse. More than half of the trees consisted of Castanopsis tribuloides (65\%) followed by Schima wallichii (16\%), Myrica esculenta (6\%), Rhododendron arboreum (5\%), Quercus lamellosa $(4 \%)$ and various other species (4\%). Although largely evergreen, the natural forest sheds a small proportion of its leaves towards the end of the dry season (FebruaryMarch) but recovers quickly thereafter. For example, the maximum measured leaf area index (LAI, using a Licor 2000 Plant Canopy Analyzer) was $5.43 \pm 0.12$ (SD) in September 2011 (i.e. at the end of the rainy season), while corresponding values measured during the premonsoon period in March, April and early June were 4.52 $\pm 0.19,5.14 \pm 0.09$, and $5.32 \pm 0.10$, respectively. The soil was classified as a Cambisol of clay loam texture. Clay content varied little with depth between 5 and $100 \mathrm{~cm}(26-29 \%)$ as did the sand (24-26\%) and silt (44-48\%) contents. Soil organic carbon (SOC) declined from $4.10 \pm 0.25 \%$ at $5-15 \mathrm{~cm}$ depths to $0.72 \pm 0.13 \%$ between 50 and $100 \mathrm{~cm}$ depths. The topsoil had a low bulk density $\left(0.93 \pm 0.08 \mathrm{~g} \mathrm{~cm}^{-3}\right.$ at $\left.5-15 \mathrm{~cm}\right)$. During soil profile excavations and in road exposures, roots were observed to penetrate into the underlying (weathered) bedrock. Depth to bedrock within the $50 \mathrm{~m} \times 50 \mathrm{~m}$ plot was ca. $2.3 \mathrm{~m}$. Further information on changes in soil characteristics with depth at this and the other two research sites is given by Ghimire et al. (2013).

Degraded Pasture: this $50 \mathrm{~m} \times 120 \mathrm{~m}$ site (1620 m a.m.s.l., southeasterly exposure, average slope angle $18^{\circ}$ ) has been heavily grazed for more than 150 years according to various local sources and is crossed by numerous footpaths. It is located $\sim 2700 \mathrm{~m}$ from the natural forest plot (Fig. 1). Numerous patches of compacted or bare soil surface were evident. The dominant grass and herb species included Imperata cylindrica, Saccharum spontaneum, and Ajuga macrosperma. Little or no grass cover remained at the peak of the dry season (March-May). The Cambisol underneath the degraded pasture plot had a silty clay texture, with a lower clay content $(12-19 \%)$ and a higher sand content (34-44\%) than the soil of the natural forest plot. Because of the intensive grazing and frequent human traffic, topsoil bulk density in the degraded pasture was significantly higher $\left(1.18 \pm 0.33 \mathrm{~g} \mathrm{~cm}^{-3}\right)$ than in the natural forest. Depth to bedrock within the plot was determined at $2.4 \mathrm{~m}$. 


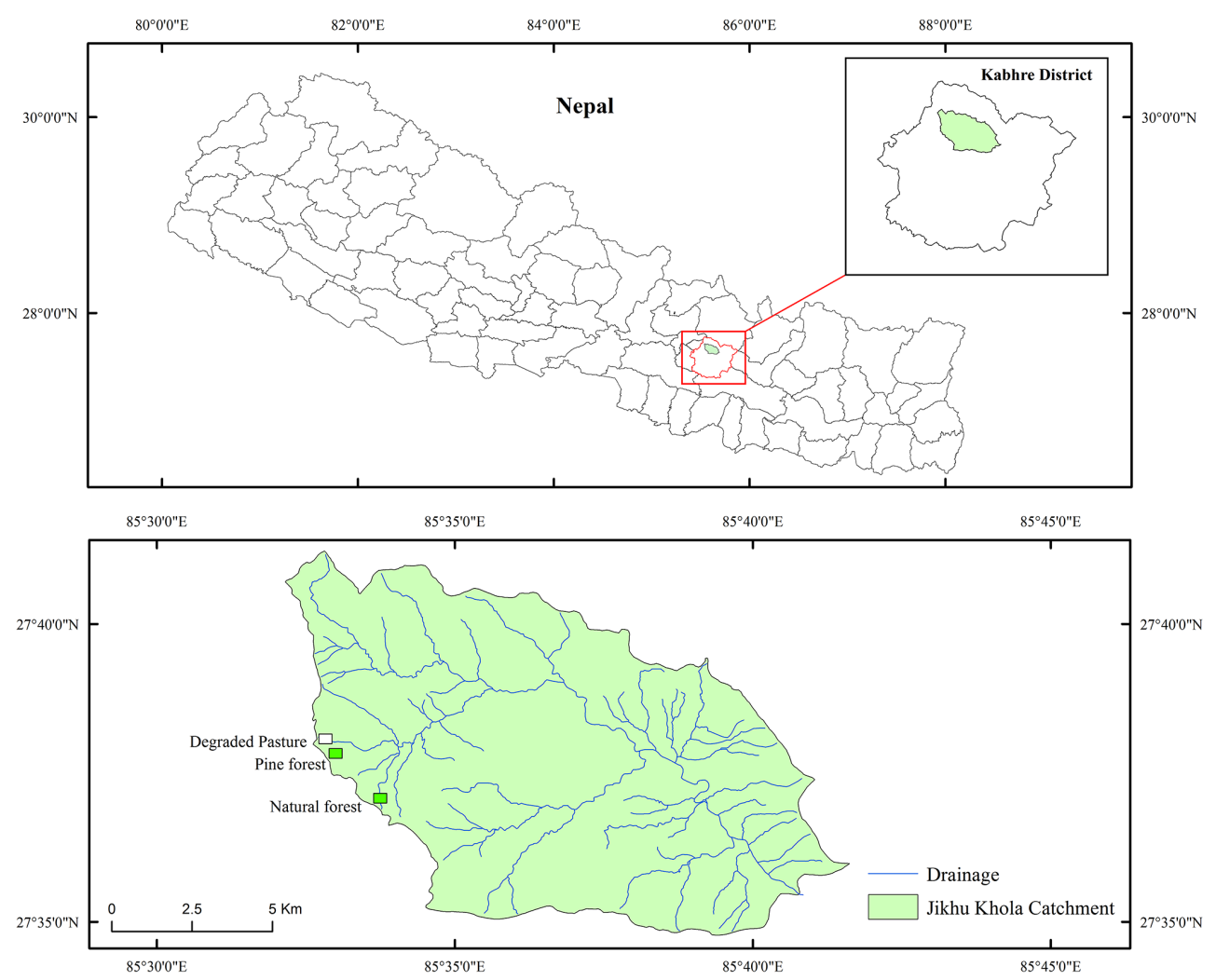

Figure 1. Location of the study sites in the Jikhu Khola catchment in the Middle Mountains of central Nepal.

Pine Forest: this former degraded pasture located approximately $400 \mathrm{~m}$ from the studied degraded pasture on a $20^{\circ}$ slope of southwesterly exposure at an elevation of $1580 \mathrm{~m}$ a.m.s.l. was planted with $P$. roxburghii in 1986 . The pine trees in the $60 \mathrm{~m} \times 60 \mathrm{~m}$ plot were 25 years old at the start of field work in June 2010. No other tree species were recorded in the plot. An understory was largely absent as grazing by cattle is common. In addition, the local population collects the litter for animal bedding and regularly harvests the grassy herb layer. Pruning of trees for fuelwood, and felling for timber are also common in the pine forests of the JKC (Schreier et al., 2006; cf. Ghimire et al., 2013a) although the research plots themselves remained free from such major disturbances throughout the present investigation. Like the dominant trees in the natural broadleaved forest, the evergreen $P$. roxburghii trees shed a proportion of their needles towards the end of the dry season but also recovered their foliage fairly quickly thereafter. The LAI of the pine forest plot was estimated at $2.21 \pm 0.10$ in September 2011 whereas corresponding values during the premonsoon period in March, April and early June were $2.05 \pm 0.14,2.15 \pm 0.12$, and $2.17 \pm 0.11$, respectively. The stem density, mean DBH and basal area as measured in May 2011 were 853 trees ha $^{-1}, 23.65 \pm 3.8 \mathrm{~cm}$ and $37.6 \mathrm{~m}^{2} \mathrm{ha}^{-1}$, respectively. The average tree height was estimated at $16.3 \pm 3.82 \mathrm{~m}$. The Cambisol underneath the pine forest plot had a silty clay texture, with a lower clay content $(11-19 \%)$ and a (much) higher sand content (40-47\%) than the soil of the natural forest or degraded pasture. Because of the regular collection of litter and associated exposure of the soil surface with erosive canopy drip, topsoil organic carbon in the pine forest was much lower $(1.7 \pm 0.3 \%)$ and bulk density significantly higher $\left(1.24 \pm 0.10 \mathrm{~g} \mathrm{~cm}^{-3}\right)$ than in the natural forest. Roots were observed to penetrate into the underlying (weathered) bedrock which occurred at a depth of ca. $1.5 \mathrm{~m}$.

\subsection{Field measurements}

\subsubsection{Environmental monitoring}

Climatic conditions were monitored by an automatic weather station located in the degraded pasture site at a distance of $400 \mathrm{~m}$ from the pine forest plot (Fig. 1). In addition, incident rainfall $(P, \mathrm{~mm})$ for each plot was recorded using a tipping bucket rain gauge (Rain Collector II, Davis Instruments, USA; $0.2 \mathrm{~mm}$ per tip) backed up by a manual gauge $\left(100 \mathrm{~cm}^{2}\right)$ that was read daily at ca. $08: 45 \mathrm{LT}$ (local time). Incoming short-wave radiation $\left(R_{\mathrm{S}}\right)$ at the pasture station was measured using an SKS 110 pyranometer (Skye Instruments, UK). The resulting radiation loads were corrected for slope aspect for use at the natural- and pine-forest sites. Air temper- 
ature $\left(T,{ }^{\circ} \mathrm{C}\right)$ and relative humidity (RH, percentage of saturation) were measured at $2 \mathrm{~m}$ height using a Vaisala HMP45C probe protected against direct sunlight and precipitation by a radiation shield. Wind speed and wind direction were measured at $3 \mathrm{~m}$ height, using an A100R digital anemometer (Vector Instruments, UK) and W200P potentiometer (Vector Instruments, UK), respectively. All measurements were recorded at 5 min intervals by a Campbell Scientific Ltd. 23X data-logger. Soil water content at each plot was measured at a single location at depths of $10,25,50$, and $75 \mathrm{~cm}$ using TDR (time domain reflectometry) sensors (CS616, Campbell Scientific Ltd.) at 30 min intervals.

\subsubsection{Forest hydrological measurements}

Wet-canopy evaporation or rainfall interception $\left(E_{\mathrm{i}}\right)$ was calculated as the difference between gross rainfall $(P)$ and net rainfall (throughfall + stemflow). Throughfall $(\mathrm{Tf}, \mathrm{mm}$ ) in the natural and pine forest plots was measured daily using 10 (pine plot) or 15 (natural forest) funnel-type collectors $\left(154 \mathrm{~cm}^{2}\right.$ orifice) that were regularly relocated in a random manner (cf. Holwerda et al., 2006). In addition, Tf was recorded continuously using three tilted stainless steel gutters in each plot $(200 \mathrm{~cm} \times 30 \mathrm{~cm} \times 15 \mathrm{~cm}$ each $)$. The throughfall measurements were carried out from 20 June to 9 September, 2011 (81 days), thereby covering the bulk of the 2011 rainy season. Stemflow (Sf, $\mathrm{mm}$ ) was measured on 10 trees which were representative of the dominant species in the natural forest plot and similarly on eight trees in the pine forest plot. Stemflow was collected using $10 \mathrm{~L}$ buckets connected to flexible polythene tubing fitted around the circumference of the trunk in a spiral fashion at $1 \mathrm{~m}$ from the ground. Stemflow measurements were carried out for 65 days between 28 July and 1 October 2010. Sf was not measured during the 2011 rainy season. Instead, the average values derived for the 2010 rainy season (expressed as a fraction of $P$ ) were used when estimating and modelling interception losses for 2011. Annual interception losses were estimated using the revised analytical model of Gash et al. (1995) which was run on a daily basis for the year between 1 June 2010 and 31 May 2011 using the forest structural and average evaporation model parameters established by Ghimire et al. (2012) for the same sites and daily rainfall values as input. A crossed sensitivity analysis was conducted using daily rainfall data from either forest site in the model to examine the effect of potentially contrasting rainfall amounts between the two sites on modelled rainfall interception totals. No significant difference was found, reflecting the fact that the distribution of daily rainfall at the two forest sites was not statistically different $(p<0.05)$. For a more detailed description of the measuring and modelling procedures used in the derivation of annual totals of $\mathrm{Tf}, \mathrm{Sf}$ and $E_{\mathrm{i}}$, the reader is referred to Ghimire et al. (2012).

The quantification of tree transpiration $\left(E_{\mathrm{t}}\right)$ was accomplished by in situ xylem sap flow rate measurements. Sap flow measurements on individual trees involve the measurement of xylem sap flux density and sap wood cross-sectional area (Granier, 1985; Lu et al., 2004; Lubczynski, 2009). Sap flux density $J_{\mathrm{p}}$ was measured primarily using thermal dissipation probes (TDP; Granier, 1985) because of their low cost, easy installation and overall simplicity, while the heat field deformation method (HFD; Nadezhdhina et al., 2012), and the heat ratio method (HRM; Burgess et al., 2001) were used in addition for the purpose of deriving radial sap flow patterns. Sapwood cross-sectional area was estimated from wood cores using an increment borer at breast height (Grissino-Mayer, 2003). Long-term monitoring of $J_{\mathrm{p}}$ was conducted on nine trees in the natural forest plot that were considered representative in terms of the dominant species present and overall size class distribution, and similarly on six trees in the pine forest plot between June 2010 and May 2011. Radial sap flow patterns were measured using the HFD method on eight trees in the pine forest and on two $C$. tribuloides trees in the natural forest for at least 3 consecutive days per tree. Similarly, radial sap flow patterns for two other dominant species (S. wallichii, $n=2 ;$ M. esculenta, $n=1$ ) were derived using the HRM. In addition, a sap flow campaign was held from March to May 2011 to capture the sap flow of additional trees that were not covered by the long-term monitoring. A total of 48 additional trees were monitored in the pine forest (distributed over four additional $30 \mathrm{~m} \times 30 \mathrm{~m}$ plots) vs. 24 trees in the natural forest (two additional $30 \mathrm{~m} \times 30 \mathrm{~m}$ plots) during this campaign using a single TDP sensor per tree. Tree-scale measurements of $J_{\mathrm{p}}$ were scaled up to the plot level using least-squares regressions between total trunk cross-sectional area and corresponding sapwood area, relations between sapwood area and $J_{\mathrm{p}}$, and information on radial changes in $J_{\mathrm{p}}$ for different tree species before summing the water uptake by all individual trees in a plot to give stand transpiration. For further details on the measurement of $J_{\mathrm{s}}$, gap filling and the scaling exercise the reader is referred to Ghimire (2014b).

To obtain approximate annual ET totals for the two forests, the respective values of wet- and dry-canopy evaporation (i.e. $E_{\mathrm{i}}$ and $E_{\mathrm{t}}$ ) were added and combined with estimates for evaporation from the understory (natural forest only given the absence of understory vegetation in the pine stand; Ghimire et al., 2014b) and from the litter layer based on findings obtained at other sites having comparable forest structural and climatic characteristics. In view of the high LAI of the natural forest (5.4), its northwesterly exposition and the generally low wind speeds, evaporative contributions by the understory were expected to be modest. Motzer et al. (2010) determined the evaporative fraction contributed by the understory at $20 \%$ of that by the overstory in a lower montane forest of comparable stature and LAI in Ecuador. This value was adopted for the Dhulikhel natural forest. Corresponding evaporation from litter layer $\left(E_{\mathrm{S}}\right)$ was considered to be low for the reasons given above and in view of the strongly seasonal rainfall regime which causes the forest floor to be 
moist for four months only. Comparative measurements of $E_{\mathrm{S}}$ in subtropical broadleaved forests are rare but Kelliher et al. (1992) determined a value of $0.3 \mathrm{~mm} \mathrm{~d}^{-1}$ in a wellwatered New Zealand forest. Translating this finding to the Dhulikhel situation and assuming the bulk of $E_{\mathrm{S}}$ to take place during the rainy season (4 months) gave an estimated value of $35 \mathrm{~mm}_{\text {year }}{ }^{-1}$. Effectively the same result ( $36 \mathrm{~mm}_{\text {year }}{ }^{-1}$ ) was obtained when applying the ratio of $E_{\mathrm{s}}$ to $E_{\mathrm{t}}$ derived for the same New Zealand forest (0.18; Kelliher et al., 1992) to the Dhulikhel forest. Thus, a value of $35 \mathrm{~mm}_{\text {year }}{ }^{-1}$ was adopted as a first estimate for $E_{\mathrm{s}}$ in the natural forest. For the more open pine forest (LAI, 2.2), one expects $E_{\mathrm{s}}$ to be somewhat higher than in the nearby natural forest. However, the pine litter is typically harvested by local people after the main leaf-shedding period (Ghimire et al., 2013, 2014a), reducing amounts of litter present and thus its moisture retention capacity. Further, a substantial fraction of the rainfall in the pine forest runs off as overland flow (see Results below), reducing $E_{\mathrm{S}}$ even further. Waterloo et al. (1999) determined $E_{\mathrm{S}}$ in a similarly stocked stand of Pinus caribaea in Fiji at $9 \%$ of the Penman open water evaporation, $E_{0}$. Applying the same fraction and taking again an effective period of 4 rainy months yielded an estimated $E_{\mathrm{S}}$ for the Dhulikhel pine forest of ca. $35 \mathrm{~mm}$ year $^{-1}$.

\subsubsection{Soil hydraulic conductivity and inferred hillslope hydrological pathways}

Field-saturated soil hydraulic conductivity $\left(K_{\mathrm{fs}}\right)$ (Talsma and Hallam, 1980; Reynolds et al., 1985) in the respective plots was measured both at the surface and at depths of $0.05-$ $0.15,0.15-0.25,0.25-0.50$, and $0.5-1.0 \mathrm{~m}$. The $K_{\mathrm{fs}}$ at different depths were subsequently combined with selected percentiles of 5 min maximum rainfall intensities $\left(\mathrm{RI}_{5 \max }\right)$ to infer the dominant hillslope hydrological response during intense rainfall following Chappell et al. (2007). A disc permeameter (Perroux and White, 1988; Mckenzie et al., 2002) was used for the measurement of surface $K_{\mathrm{fs}}$ in the field and a constant-head well permeameter (CHWP; Talsma and Hallam, 1980) for the measurement of $K_{\mathrm{fs}}$ in deeper layers. Use of the CHWP was restricted to the dry season to minimise errors from smearing of the auger hole walls (Chappell and Lancaster, 2007). For surface $K_{\mathrm{fs}}, 10$ (pine forest) to 17 (degraded pasture) replicate measurements were made whereas for subsurface $K_{\mathrm{fs}}, 45-80$ auger holes were used per site. For a detailed description of the measuring procedures and sampling strategy, the reader is referred to Ghimire et al. (2013).

\subsubsection{Overland flow}

Overland flow (OF) at the natural forest, degraded pasture and pine forest sites was monitored between 20 June and 9 September 2011 (i.e. the bulk of the 2011 rainy season) using a single, large $(5 \mathrm{~m} \times 15 \mathrm{~m})$ runoff plot per land-cover type. Runoff was collected in a gutter funneling the water to a first $180 \mathrm{~L}$ collector equipped with a seven-slot divider system allowing only one-seventh of the spillover into a second $180 \mathrm{~L}$ drum, thereby bringing the total collector capacity to $1440 \mathrm{~L}(\sim 20 \mathrm{~mm})$. The water levels in the two collectors were measured continuously using a pressure transducer device (Keller, Germany) placed at the bottom. Collectors were emptied and cleaned after measuring the water level manually every day at around 08:45 LT. Event runoff volume was calculated by converting the water levels to volumes using a precalibrated relationship per drum and summing up to obtain total runoff volume. Measured overland flow volumes were corrected for direct rainfall inputs into the runoff collecting system. Overland flow volumes were divided by the projected plot area to give overland flow in millimetres per event.

\subsubsection{Grassland evaporation}

The HYDRUS-1D model for one-dimensional soil water movement (Šimůnek et al., 2008) was used to estimate evaporation from the degraded pasture site. Like most pastures in the area, the site was heavily overgrazed (Gilmour et al., 1987; Ghimire et al., 2014a, b) and the capacity of the grass to intercept rainfall was considered negligible. Likewise, in view of the very limited live biomass of the grass, transpiration was also considered minimal. Hence, overall, evaporation at the grassland site was set equal to soil evaporation defined by HYDRUS-1D model (Šimůnek et al., 2008). The HYDRUS-1D model is based on the modified Richard's equation. In this study it was assumed that the gaseous phase plays an unimportant role in the overall vapour transport due to thermal gradients.

The modelling was divided into three parts: (i) model calibration against measured soil moisture data (1 September30 November 2010) using optimisation, (ii) model validation using data collected between 1 February and 31 March 2011, and (iii) complete simulation of soil water dynamics and evaporation for the entire annual period (1 June 201031 May 2011). The $1 \mathrm{~m}$-deep soil column was divided into four schematic layers as follows: (i) $0-0.15 \mathrm{~m}$, (ii) $0.15-$ $0.25 \mathrm{~m}$, (iii) $0.25-0.50 \mathrm{~m}$, and (iv) $0.50-1.0 \mathrm{~m}$.

The soil physical parameters employed in HYDRUS-1D include $Q_{\mathrm{r}}$ for the residual water content and $Q_{\mathrm{s}}$ for the saturated water content, as well as the two parameters, $\alpha$ and $n$, describing the shape and range of the soil water retention curve and the derived relative hydraulic conductivity curve (Van Genuchten, 1980). Other model parameters include the saturated hydraulic conductivity $\left(K_{\mathrm{s}}\right)$, and $I$, a pore-connectivity parameter. All parameters were optimised except for $K_{\mathrm{S}}$ which was measured separately for each layer in the field using well permeametry as described above. The parameters were optimised by fitting observed and modelled soil moisture values using the Marquardt-Levenberg optimisation algorithm. The model was run on an hourly basis. The boundary conditions used in the model were the atmospheric 

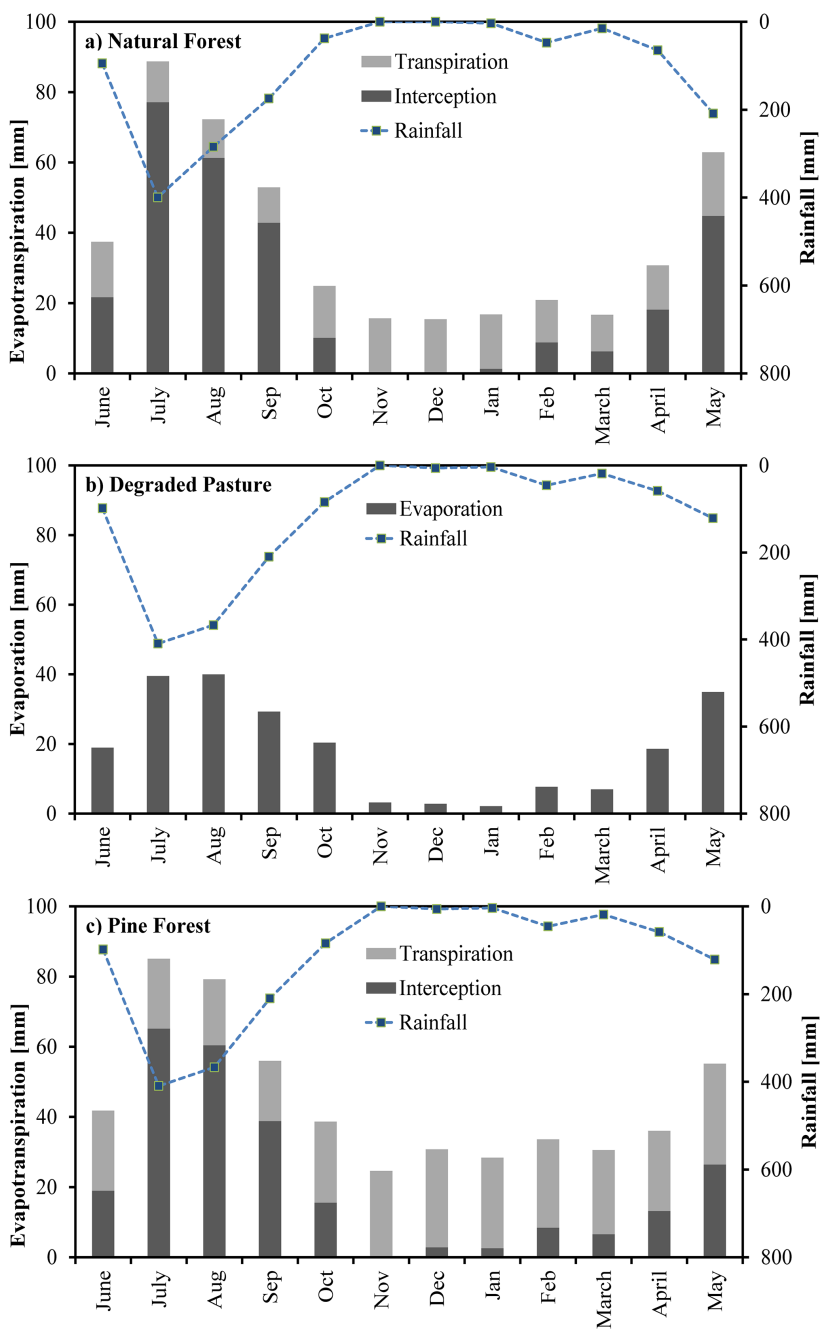

Figure 2. Monthly rainfall, interception and transpiration totals (mm) between 1 June 2010 and 31 May 2011 in (a) natural broadleaved forest, (b) degraded pasture, and (c) planted pine forest near Dhulikhel, central Nepal.

boundary (soil surface) with surface runoff occurrence, and free drainage at the lower boundary.

\section{Results}

\subsection{Evapotranspiration}

Figure 2 shows the monthly variation in ET and its two main components, rainfall interception and transpiration, for the three land-cover types studied between 1 June 2010 and 31 May 2011 whereas the respective seasonal and annual evapotranspiration totals are presented in Table 1.

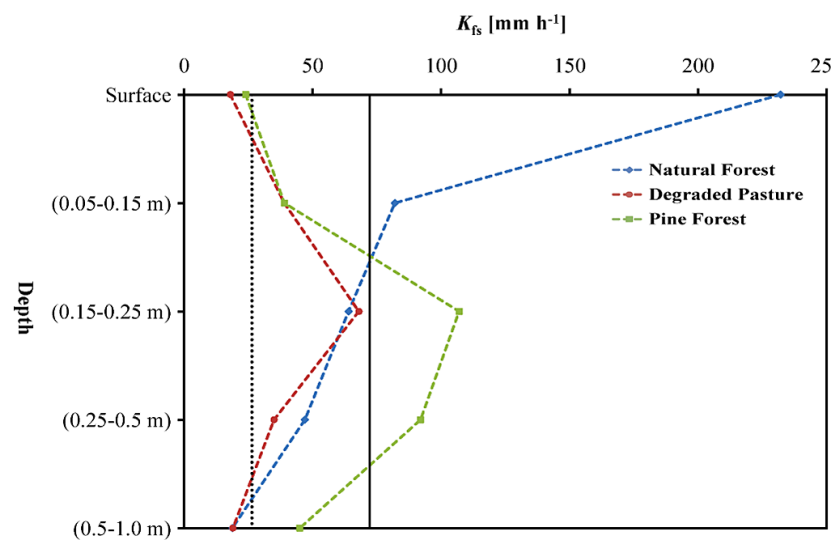

Figure 3. Changes in field-saturated hydraulic conductivity $K_{\mathrm{fs}}$ with depth as a function of land use near Dhulikhel, central Nepal. The dotted and solid horizontal lines represent the median and 95 percentile of $\mathrm{RI}_{5 \max }$ rainfall intensity, respectively (modified after Ghimire et al., 2013).

Although the seasonal patterns for ET were similar between vegetation types, monthly ET totals were generally higher for the planted pine forest and lower in the degraded pasture throughout the monitoring period (Fig. 2). All three sites showed higher ET rates and monthly totals during the wet season months (June-September) compared to the dry season months (October-April), with the transitional month of May (marking the first return of the rains; Fig. 2a) showing intermediate values. Such findings can be attributed largely to the (much) higher frequency of wetting and subsequent drying (evaporation) during the wet season (cf. Table 1).

As found earlier for monthly ET totals, the annual ET for the planted forest was the highest for all three vegetation types studied $(577 \mathrm{~mm})$, being two and a half times larger than the annual ET in the degraded pasture $(225 \mathrm{~mm}$; Table 1). The annual ET for the natural forest was $524 \mathrm{~mm}$, which is $53 \mathrm{~mm}$ less than that for the nearby pine forest but $300 \mathrm{~mm}$ higher than the ET of the degraded pasture (Table 1). Whilst absolute rainfall interception totals did not differ much between the natural and the planted forest $\left(31 \mathrm{~mm}\right.$ year $^{-1}$ higher in the broadleaved forest despite a slightly lower rainfall total), both the seasonal and annual transpiration totals were distinctly higher for the pine forest (Table 1). Wet-season transpiration in the pine forest was $20 \mathrm{~mm}$ higher vs. $64 \mathrm{~mm}$ during the dry season.

\subsection{Soil hydraulic conductivity, overland flow and subsurface flow paths}

As expected on the basis of the degree of anthropogenic pressure experienced by the respective sites, the median surface $K_{\mathrm{fs}}$ was lowest for the degraded pasture $\left(18 \mathrm{~mm} \mathrm{~h}^{-1}\right)$ and highest for the natural forest $\left(232 \mathrm{~mm} \mathrm{~h}^{-1}\right)$, such that the two differed by more than an order of magnitude (Fig. 3). The most striking feature of the $K_{\mathrm{fs}}$ data set is that the me- 
Table 1. Summary of rainfall and estimated evapotranspiration components for a natural broadleaved forest, a degraded grassland, and a mature planted pine forest near Dhulikhel, Middle Mountains, central Nepal.

\begin{tabular}{|c|c|c|c|c|c|c|c|c|c|}
\hline & \multicolumn{3}{|c|}{ Natural forest } & \multicolumn{3}{|c|}{ Degraded pasture } & \multicolumn{3}{|c|}{ Pine forest } \\
\hline & Wet & Dry & Total & Wet & Dry & Total & Wet & Dry & Total \\
\hline Rainfall $(P, \mathrm{~mm})$ & 953 & 378 & 1331 & 1084 & 338 & 1423 & 1084 & 338 & 1423 \\
\hline Transpiration $\left(E_{\mathrm{t}}, \mathrm{mm}\right)$ & 48 & 115 & 163 & - & - & - & 78 & 202 & 280 \\
\hline Interception $\left(E_{\mathrm{i}}, \mathrm{mm}\right)$ & 203 & 90 & 293 & - & - & - & 184 & 78 & 262 \\
\hline Grassland soil evaporation & - & - & - & 128 & 97 & 225 & - & - & - \\
\hline Understory evaporation $\left(E_{\mathrm{us}}, \mathrm{mm}\right)$ & - & - & 33 & - & - & - & - & - & - \\
\hline Litter evaporation $\left(E_{\mathrm{S}}, \mathrm{mm}\right)$ & 35 & - & 35 & - & - & - & 35 & - & 35 \\
\hline Total evapotranspiration (ET, mm) & 286 & 205 & 524 & 128 & 97 & 225 & 297 & 280 & 577 \\
\hline
\end{tabular}

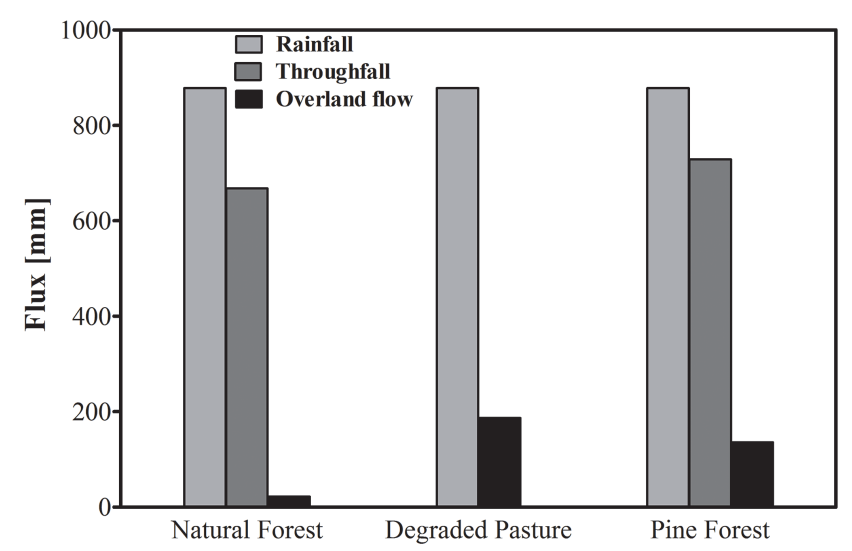

Figure 4. Amounts of rainfall, throughfall and overland flow (mm) during the 2011 monsoon measuring campaign (20 June-9 September) in a natural forest, a degraded pasture, and a mature, intensively used pine plantation near Dhulikhel, central Nepal. Note that values for the natural forest plot were normalised for rainfall amount to allow for more direct comparisons.

dian $K_{\mathrm{fs}}$ at the surface and in the shallow soil layer in the 25-year-old pine forest had remained at the same level as the corresponding values for the heavily grazed pasture, suggesting the virtually complete absence of biologically mediated macropores in the pine forest soil down to $0.15 \mathrm{~m}$ depth. At $1.0 \mathrm{~m}$ depth, however, differences in $K_{\mathrm{fs}}$ between the respective land-cover types were mostly non-existent (except for the higher value beneath the pine forest reflecting the much higher sand content listed in the site description), illustrating the lack of influence exerted by cattle grazing and human trampling on the deeper soil layers.

Importantly, the surface $K_{\mathrm{fs}}$ in the natural forest exceeded the maximum values of $\mathrm{RI}_{5 \max }$, suggesting infiltrationexcess overland flow (IOF) would never occur at this site. Nevertheless, some overland flow was recorded (Fig. 4) with a monsoonal total of $18 \mathrm{~mm}(22 \mathrm{~mm}$ after normalising for the higher rainfall observed at the other two sites) representing $2.5 \%$ of incident rainfall and $3.3 \%$ of the corresponding amount of throughfall. Given the much lower median
$K_{\mathrm{fs}}$ derived for the $0.05-0.15 \mathrm{~m}$ depth interval in the natural forest $\left(82 \mathrm{~mm} \mathrm{~h}^{-1}\right.$; Fig. 3), it cannot be excluded that at least some of the recorded overland flow was contributed by the saturation-excess type (SOF) (Bonell, 2005). The median surface $K_{\mathrm{fs}}$ values in the degraded pasture and pine forest were below the upper quartile of $\mathrm{RI}_{5 \max }$, thereby indicating the frequent occurrence of IOF during high-intensity rainfall (Fig. 3). Indeed, overland flow at the degraded pasture site was typically generated after 3-4 mm of rain while the seasonal (monsoonal) overland flow total amounted to $187 \mathrm{~mm}$ ( $21.3 \%$ of incident rainfall; Fig. 4). Corresponding values for the pine forest were comparable at $4.2 \mathrm{~mm}$ of rain before overland flow would start and a seasonal total of $136 \mathrm{~mm}$ ( $15.5 \%$ of rainfall and $18.6 \%$ of throughfall; Fig. 4).

With regard to $K_{\mathrm{fs}}$ in the $0.05-0.15 \mathrm{~m}$ layer, although the upper quartile of $\mathrm{RI}_{5 \max }$ exceeded the median $K_{\mathrm{fs}}$ values for this depth interval at both the degraded pasture and pine forest sites (Fig. 3), the actual volumes of water reaching this layer are necessarily restricted by the low value of the surface "throttle" at both sites. Surface $K_{\mathrm{fs}}$ at either site did not exceed the $K_{\mathrm{fs}}$ at $0.05-0.15 \mathrm{~m}$ depth and therefore no perched water table can develop and hence no shallow lateral subsurface stormflow (SSF) is generated at either site. In contrast, the corresponding median $K_{\mathrm{fs}}$ at the natural forest is still above (or nearly equal to) most 5 min rainfall intensities, thereby favouring mostly vertical percolation at this site. For the $0.15-0.25$ and $0.25-0.50 \mathrm{~m}$ depth intervals, the $K_{\mathrm{fs}}$ values in the natural forest indicated a similar hydrological response to extreme rainfall, namely mostly lateral SSF because of limited vertical percolation under such conditions (cf. Fig. 3). Finally, at $1.0 \mathrm{~m}$ depth, the differences in $K_{\mathrm{fs}}$ and inferred hydrological response to rainfall became insignificant between sites (Fig. 3).

\subsection{Site water budgets}

Combining the above mentioned overland flow percentages for the pine forest and degraded pasture with a long-term mean annual site rainfall of $1500 \mathrm{~mm}$ (Merz, 2004), the difference in approximate annual IOF between the two land 
Table 2. Summary of changes in annual ET ( $\mathrm{mm})$ and $\mathrm{OF}(\mathrm{mm})$, and the resultant gains in infiltration $(\mathrm{mm})$ and evaporative losses ( $\mathrm{mm})$ when converting degraded pasture to (heavily used) planted pine forest or (little disturbed) natural broadleaved forest near Dhulikhel, central Nepal. Note that overland flow amounts were calculated for a mean annual site rainfall of $1500 \mathrm{~mm}$ (Merz, 2004). Note that all values are rounded off to the nearest fifth or tenth.

\begin{tabular}{lrrrrr}
\hline $\begin{array}{l}\text { Experimental } \\
\text { plot }\end{array}$ & $\begin{array}{r}\text { ET } \\
(\mathrm{mm})\end{array}$ & $\begin{array}{r}\text { OF } \\
(\mathrm{mm})\end{array}$ & $\begin{array}{r}\text { Gain } \\
(\mathrm{mm})\end{array}$ & $\begin{array}{r}\text { Loss } \\
(\mathrm{mm})\end{array}$ & $\begin{array}{r}\text { Overall net } \\
\text { effect }(\mathrm{mm})\end{array}$ \\
\hline $\begin{array}{l}\text { Degraded pasture } \\
\text { Pine forest }\end{array}$ & 575 & 320 & - & - & - \\
Natural forest & 525 & 35 & 285 & 300 & -260 \\
\hline
\end{tabular}

covers represents a gain in infiltration of approximately $90 \mathrm{~mm}$ year $^{-1}$ under the planted pine forest relative to the degraded grass land (Table 2). However, the relative amounts of surface evaporation/transpiration in the degraded pasture and the pine forest, plus the added rainfall interception losses from the pine forest, suggest a difference in annual evapotranspiration of $\sim 350 \mathrm{~mm}$ year $^{-1}$ after reforestation and stand maturation (Table 2). Thus, the added loss through ET is greatly in excess of the estimated gain in infiltration of $90 \mathrm{~mm}_{\text {year }}{ }^{-1}$ after reforestation causing a net loss of $\sim 260 \mathrm{~mm}$ year $^{-1}$. Repeating the exercise for the natural forest (with an estimated annual ET of $\sim 525 \mathrm{~mm}$ and very low overland flow production) suggests the approximate gain in infiltration $\left(285 \mathrm{~mm}_{\text {year }}{ }^{-1}\right)$ and the extra evaporative loss $\left(300 \mathrm{~mm} \mathrm{year}^{-1}\right.$ ) are both very similar (Table 2$)$, implying no major change in moisture availability and dry season flow under mature natural forest conditions.

\section{Discussion and conclusions}

\subsection{Human impact on forest hydrological functioning - an understudied dimension}

The results obtained for the respective water balance components suggest that soil water replenishment and retention during the monsoon are largely controlled by surface and subsurface soil hydraulic conductivities and the resultant partitioning of rainfall into overland flow, lateral subsurface flow and deep percolation (Table 1, Fig. 3). As long as rainfall intensities remain below the surface $K_{\mathrm{fs}}$ threshold for overland flow to occur, soil water reserves are being recharged. However, for intensities above this threshold a major proportion of the rain is redirected laterally over the surface as overland flow and less water is available for soil moisture replenishment. The high surface and near-surface $K_{\mathrm{fs}}$ in the natural forest $\left(82-232 \mathrm{~mm} \mathrm{~h}^{-1}\right)$ ruled out IOF occurrence and favour vertical percolation. In contrast, the corresponding $K_{\mathrm{fs}}$ values for the planted forest and degraded pasture were conducive to IOF generation during medium- to high-intensity storms which represents an important net loss of moisture to these hillslopes (Fig. 3, Table 2).

Marked reductions in surface- and near-surface $K_{\mathrm{fs}}$ after converting tropical forest to grazed pasture have been observed in many cases (Alegre and Cassel, 1996; Tomasella and Hodnett, 1996; Deuchars et al., 1999; Zimmermann et al., 2006; Molina et al., 2007; Tobón et al., 2010) and the Himalayas are no exception (Patnaik and Virdi, 1962; Gilmour et al., 1987; Gerrard and Gardner, 2002; Ghimire et al., 2013, 2014a). The low surface and near-surface $K_{\mathrm{fs}}$ reported for grazing conditions is mostly the result of destroyed macroporosity through trampling by cattle and by the much diminished soil faunal activity after forest clearing and burning with the associated loss of topsoil organic matter and surface exposure with erosive precipitation (McIntyre, 1958a, b; Lal, 1988; Deuchars et al., 1999; Colloff et al., 2010; Bonell et al., 2010). Natural forest regrowth on degraded pasture or planting trees followed by uninterrupted plantation development can be expected to gradually improve the soil water intake capacity again through the steady incorporation of organic matter, soil faunal and insect burrowing activity, and root turnover (Gilmour et al., 1987; Bonell, 2005; Ilstedt et al., 2007; Bonell et al., 2010; Colloff et al., 2010; Hassler et al., 2011; Perkins et al., 2012). Conversely, impervious footpaths, yards and roads will remain runoff-producing features in post-forest landscapes (Ziegler et al., 2004; Rijsdijk et al., 2007) as well as in managed (forest) plantation areas (La Marche and Lettenmaier, 2001; Ziegler et al., 2007; Liu et al., 2009). Likewise, the surface hydraulic conductivity of the intensively used pine forest showed little improvement even 25 years after the trees were planted (Fig. 3). Clearly, the continued human access, grazing and collection of forest products (notably litter from the forest floor to be used for animal bedding and composting; Singh and Sundriyal, 2009; Joshi and Negi, 2011) is having a profound negative effect on the stand's hydrological functioning (cf. Ghimire et al., 2013, 2014a). Thus, the general expectation of restored surface and near-surface $K_{\mathrm{fs}}$ with time after reforestation (cf. Gilmour et al., 1987; Ilstedt et al., 2007) is in need of modification under the conditions of high anthropogenic pressure that appear to be the rule rather than the exception in the Middle Mountain zone (Singh et al., 1984; Mahat et al., 1987; Singh and Sundriyal, 2009; Joshi and Negi, 2011) despite claims to the contrary (HURDEC Nepal and Hobley, 2012). Indeed, if the potential benefits of reforestation such as enhanced infiltration, and therefore possibly improved replenishment of soil water and groundwater reserves are to be realised, then a balance will need to be struck between the continued usage of the forests by uplanders whose livelihoods are at stake and sustained forest hydrological functioning (Ghimire et al., 2014a). Naturally, this holds for many other densely populated tropical uplands as well (e.g. Ding et al., 1992; Van Noordwijk et al., 2001; Forsyth and Walker, 2008; Van Noordwijk and Leimona, 2010). 


\subsection{Trade-off between changes in vegetation water use and surface infiltration after reforestation}

The infiltration trade-off hypothesis states that the ultimate hydrological effect of reforestation in terms of site water yield is determined by the net balance between increases in soil water reserves afforded by improved soil infiltration versus decreases caused by the higher plant water uptake (Bruijnzeel, 1986, 1989). In the absence of direct published evidence of improved dry season flows after reforestation (Jackson et al., 2005; Farley et al., 2005) at the time, Scott et al. (2005) discussed a number of tropical studies that had observed marked reductions in stormflow production at the hillslope (e.g. Zhang et al., 2004; Chandler and Walter, 1998) or small-basin scale (e.g. Zhou et al., 2002) after reforesting severely degraded land. They concluded that in a number of cases the increases in water retention should be more than enough to compensate the estimated corresponding increases in forest water use (not measured). It is unfortunate that the catchments involved did not sustain perennial flows and thus the presumed net positive effect of forestation on dry season flows could not be confirmed (Scott et al., 2005; cf. Chandler, 2006). Nevertheless, recently published evidence from southern China (Zhou et al., 2010), South Korea (Choi and Kim, 2013) and southwestern India (Krishnaswamy et al., 2012, 2013) strongly suggests a net positive outcome of the infiltration trade-off mechanism is possible as long as the initial situation is sufficiently degraded and the site receives ample rainfall (cf. Bruijnzeel et al., 2013).

Such experimental catchment studies usually comprise measurement of the change in streamflow following reforestation but generally lack detailed supporting process-based observations within the catchment undergoing the change (Farley et al., 2005; Scott et al., 2005). As such, the present process-based work which integrated the dominant hydrological processes (notably evaporation, infiltration and runoff generation) to quantify the net hydrological impact of reforestation is a first (cf. Chandler, 2006; Bonell et al., 2010; Krishnaswamy et al., 2013). Comparing the hydrological behaviour of the three contrasting land-cover types studied here (degraded pasture, mature near-undisturbed broadleaved forest, and a heavily used mature pine plantation) within the context of the infiltration trade-off hypothesis showed that planting pines increased vegetation water use relative to the pasture situation by $\sim 350 \mathrm{~mm}$ year $^{-1}$ (Table 1 ). On balance, the limited amount of extra infiltration afforded by the pine trees $\left(\sim 90 \mathrm{~mm}\right.$ year $\left.^{-1}\right)$ is clearly insufficient to compensate the much higher water use of the pines, giving a net negative balance of $260 \mathrm{~mm}_{\text {year }}{ }^{-1}$ (Table 2, Fig. 4). Pertinently, the net effect would still have been negative (by $\sim 120 \mathrm{~mm}$ year $^{-1}$ ) even if all rainfall would have been accommodated by the pine forest soil through better forest and soil management promoting infiltration (cf. Wiersum, 1985). As such, the observed decline in dry season flows following reforestation in the study area (República, 2012) is likely to

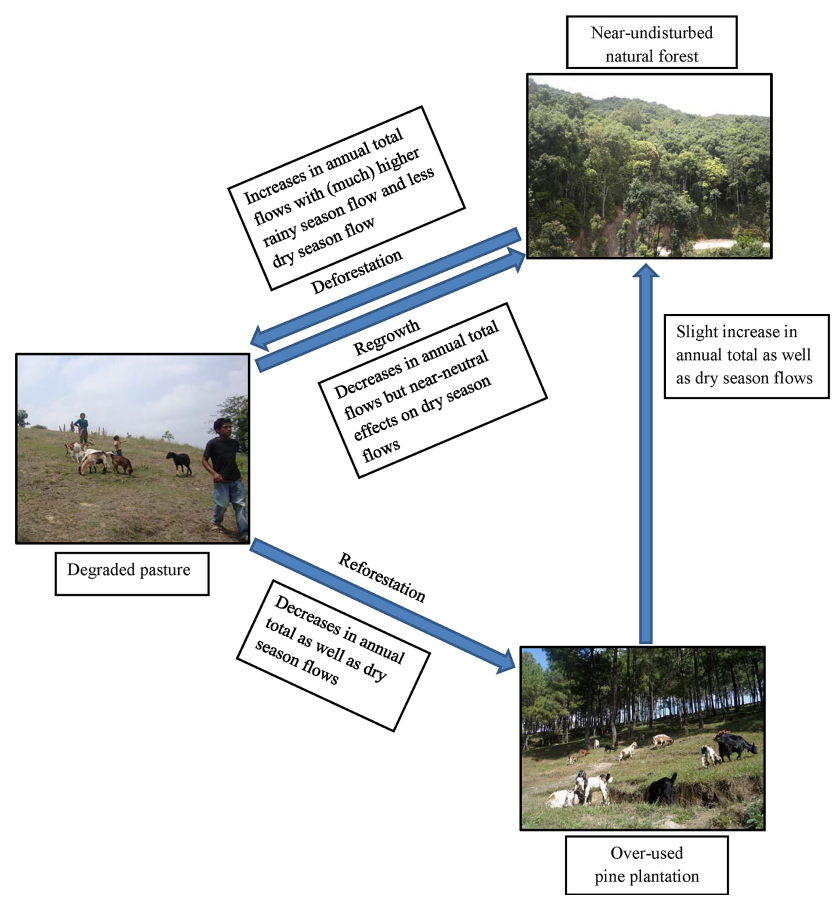

Figure 5. Conceptual diagram of the effect of land-cover transformation on annual total and dry season flows in the study area as well as other comparable regions with similar land-cover transformations.

primarily reflect the higher water use of the pines (Tables 1 , 2; Fig. 5).

If the degraded pasture were to revert to natural forest instead (with an estimated annual ET of $525 \mathrm{~mm}$ and very limited overland flow production) the ultimate effect on dry season flows would be expected to be near neutral as the approximate gain in infiltration $\left(\sim 285 \mathrm{~mm}\right.$ year $\left.^{-1}\right)$ and the extra evaporative loss $\left(\sim 300 \mathrm{~mm}^{-1}\right.$ year $\left.^{-1}\right)$ are very similar (Table 2). Effects might be more negative in case the water use of the young regenerating broadleaved forest turned out to be enhanced compared to old-growth forest as found for lowland tropical and warm temperate forests (Vertessy et al., 2001; Giambelluca, 2002).

Although the present finding of a slightly higher ET ( $\sim 10 \%$; Table 1) for planted forest compared to natural broadleaved forest is not going to have major hydrological consequences on an annual basis, the much higher water use of the pines during the dry season (Table 1, Fig. 1) is likely to result in a corresponding reduction in dry season water yield upon converting natural broadleaf forest to pine plantations (Fig. 5), especially during the more vigorous early growth stage of the pines (Bruijnzeel, 1997; Scott and Prinsloo, 2008; Alvarado-Barrientos, 2013). The present results further illustrate that the conditions found in the nearly undisturbed natural broadleaved forest and in similarly wellmaintained forests elsewhere in the Himalaya (Pathak et al., 1984; Gerrard and Gardner, 2002) will encourage the replen- 
ishment of soil water and groundwater reserves through vertical percolation (geology permitting) more than in any other land-cover type studied here (Fig. 5; cf. Choi and Kim, 2013; Krishnaswamy et al., 2013) and thus better sustain baseflows during the long dry season (Hessel et al., 2007; Tiwari et al., 2011). The importance of the latter in the water-scarce Middle Mountain zone can hardly be overemphasised (Merz et al., 2003; Schreier et al., 2006; Bandyopadhyay, 2013).

\subsection{Regional implications}

The Himalayan river basins are home to about 1.3 billion people and supply water, food and energy to more than 3 billion people in total (Bandyopadhyay, 2013). Thus, largescale changes in Himalayan land use and hydrology will have important regional consequences. For example, substantial decreases in dry season flows following advanced surface degradation (Bartarya, 1989; Madduma Bandara, 1997) or large-scale reforestation (cf. Trimble et al., 1987; Zhou et al., 2010) would affect the availability of water for millions of people, both those depending directly on agriculture for their livelihoods and downstream city dwellers. Therefore, largescale reforestation campaigns and the subsequent use of the planted forests must be based on a sound assessment of what is to be expected hydrologically (Peña-Arancibia et al., 2012; Van Dijk et al., 2012) and meteorologically (Ellison et al., 2011). Precipitation fluctuations in Nepal and northern India have been shown to be strongly influenced by surface temperatures in the Indian Ocean and southwestern Pacific, with dry years coinciding mostly with ENSO (El Niño-Southern Oscillation) events and wet years with La Niña events (Shrestha et al., 2000; Yadav, 2009; Varikoden et al., 2014). Therefore, the influence (if any) of increased forest cover on rainfall in this strongly seasonal environment remains to be ascertained (Basistha et al., 2009). Although continued global warming is predicted to ultimately lead to an increase in precipitation in the Himalayas, such predictions are subject to major uncertainty with respect to the inclusion of aerosol effects and large-scale irrigation in the adjacent plains (Craig Collier and Zhang, 2009; Mathison et al., 2012; Kumar et al., 2013).

The presently observed negative hydrological effect of an apparently long-term trend of gradual forest degradation in the Nepalese Middle Mountain zone goes against the optimistic notion regarding the overall improved quality of Lesser Himalayan forests expressed by HURDEC Nepal and Hobley (2012). However, there is reason to believe that the situation of over-intensive use of forests and the correspondingly poor soil hydrological functioning are a rather more widespread phenomenon in Nepal's Lesser Himalaya. For example, Gerrard and Gardner (2002) reported very high overland flow occurrence in degraded (broadleaved) forests in the Likhu Khola catchment north of Kathmandu, whereas Tiwari et al. (2009) and Wester (2013) recently presented similar evidence for community-managed forests further west in Nepal. Although process-based hydrological evi- dence to this effect from the Indian Himalaya is scarce (Negi, 2002; Tiwari et al., 2011; Tyagi et al., 2013) the continued overexploitation of its forest resources is well-documented (Singh et al., 1984; Singh and Sundriyal, 2009; Joshi and Negi, 2011). Such situations may significantly reduce the recharge of shallow groundwater reserves during the monsoon season, thereby potentially decreasing regional dry season flows (Bartarya, 1989; cf. Andermann et al., 2012).

A key message of the present work thus is the need to protect the remaining natural forests in headwater areas throughout the Middle Mountain zone. The present findings further highlight the need for some form of protection of reforested areas that will enable the forest soils to realise the enhanced infiltration/percolation benefits envisaged at the time of planting. Alternative sources of energy to replace fuelwood (e.g. biogas) may take off some of the pressure on the forests (cf. Schreier et al., 2006). Continued degradation of the remaining old-growth forests and planted forests that are now reaching maturity is likely to cause further increases in overland flow production during the monsoon season due to the corresponding decline in infiltration opportunities (Ghimire et al., 2014a). This may, in turn, have a further negative effect on already declining dry season flows and will cause increased hardship to the rural populace (Merz et al., 2003; Schreier et al., 2006). Finally, and most importantly, the present results point to the need for balancing the societal and hydrological functions of forests (both planted and natural) in densely populated uplands. Like elsewhere in Asia (e.g. Tomich et al., 2004; Hairiah et al., 2006), agroforests appear to represent a viable alternative that is on the increase in Nepal (Schreier et al., 2006; Gilmour and Shah, 2012). Not only do they contain a variety of tree and crop species serving a range of uses as opposed to the monospecific character of most planted forests but agroforests are also likely to consume less water (e.g. Wallace et al., 2005) while minimising surface runoff and erosion, thereby maintaining adequate levels of rainfall infiltration (Wiersum, 1984; cf. Hairiah et al., 2006).

Acknowledgements. We dedicate this work to our co-author, friend and colleague Mike Bonell who passed away during the revision stage of the paper. This study was supported financially by the Faculty of Earth and Life Sciences of the VU University Amsterdam (FALW-VUA) and by the Faculty of Geo-Information Science and Earth Observation (ITC-UT) of the University of Twente, Enschede, the Netherlands. Additional financial support was also received from the Royal Society, UK, through the University of Dundee. Neil Coles, Centre for Ecohydrology at the University of Western Australia, is also thanked for his loan of the disc permeameters and support in the associated logistics in the early stages of the field campaign. We acknowledge the indispensable help in the field received from Paras Poudel, Suraj Karki, Sudish Lal Maskey, Umesh Karki, Laxman Baniya, Khadga Bahadur Kharel, Dawa Lama and Kapil Gyawali. We especially would like to thank Pruna Bahadur Magar and his family for their hospitality and support during the field campaign. Enrico Balugani 
is thanked for his help with the HYDRUS-1D simulation. Michel Groen (VUA) and Murat Ulcer (ITC-UT) supplied and constructed equipment. Last but not least, we are grateful to D. Tongway, K. Farrick, and M. van Noordwijk for their constructive comments.

Edited by: N. Romano

\section{References}

Alegre, J. C. and Cassel, D. K.: Dynamics of soil physical properties under alternate systems to slash-and-burn, Agricultural, Ecosyst. Environ., 58, 39-48, 1996.

Allen, R. G., Pereira, L. S., Raes, D., and Smith, M.: Crop evapotranspiration - Guidelines for computing crop water requirements, United Nations Food and Agriculture Organization, Rome, 1998.

Alvarado-Barrientos, M. S., Hernandez-Santana, V., and Asbjornsen, H.: Variability of the radial profile of sap velocity in $\mathrm{Pi}$ nus patula from contrasting stands within the seasonal cloud forest zone of Veracruz, Mexico, Agr. Forest Meteorol., 168, 108119, 2013.

Andermann, Ch., Longuevergne, L., Bonnet, S., Crave, A., Davy, Ph., and Gloaguen, R.: Impact of transient groundwater storage on the discharge of Himalayan rivers, Nat. Geosci., 5, 127-132, 2012.

Andréassian, V.: Water and forests: From historical controversy to scientific debat, J. Hydrol., 291, 1-27, 2004.

Angelini, I. M., Garstang, M., Davis, R. E., Hayden, B., Fitzjarrald, D.R., Legates, D. R., Greco, S., Macko, S., and Connors, V.: On the coupling between vegetation and the atmosphere, Theor. Appl. Climatol., 105, 243-261, 2011.

Bai, Z. G., Dent, D. L., Olsson, L., and Schaepman, M. E.: Proxy global assessment of land degradation, Soil Use Manage., 24, 223-234, 2008.

Bandyopadhyay, J.: Sustaining the Himalaya as the water tower of Asia: On the need for innovative policy making from India and China, 19th Pundit Govind Ballabh Pant memorial lecture, 10 September 2013, G.B. Pant Institute of Himalayan Environment and Development, Almora, India, 19 pp., 2013.

Bartarya, S. K.: Hydrogeology, geo-environmental problems and watershed management strategies in a central Himalayan river basin, Kumaun, India, in: Headwater Control, edited by: Kreek, J. and Haigh, M. J., IUFRO/WASWC/CSVIS, Plzen, Czechoslovakia, 308-318, 1989.

Basistha, A., Arya, D. S., and Goel, N. K.: Analysis of historical changes in rainfall in the Indian Himalayas, Int. J. Climatol., 29, 555-572, 2009.

Bonell, M.: Runoff generation in tropical forests, in: Forests, Water and People in the Humid tropics, edited by: Bonell, M. and Bruijnzeel, L. A., Cambridge University Press, Cambridge, UK, 314-406, 2005.

Bonell, M., Purandara, B. K., Venkatesh, B., Krishnaswamy, J., Acharya, H. A. K., Singh, U. V., Jayakumar, R., and Chappell, N.: The impact of forest use and reforestation on soil hydraulic conductivity in the Western Ghats of India: Implications for surface and sub-surface hydrology, J. Hydrol., 391, 47-62, 2010.
Bookhagen, B. and Burbank, D. W.: Topography, relief, and TRMM-derived rainfall variations along the Himalaya, Geophys. Res. Lett., 33, L08405, doi:10.1029/2006GL026037, 2006.

Bookhagen, B. and Burbank, D. W.: Toward a complete Himalayan hydrological budget: spatiotemporal distribution of snowmelt and rainfall and their impact on river discharge, J. Geophys. Res., 115, F03019, doi:10.1029/2009JF001426, 2010.

Bosch, J. M. and Hewlett, J. D.: A review of catchment experiments to determine the effect of vegetation changes on water yield and evapo-transpiration, J. Hydrol., 55, 3-23, 1982.

Brown, A. E., Zhang, L., McMahon, T. A., Western, A. W., and Vertessy, R. A.: A review of paired catchments studies for detremining changes in water yield resulting from alterations in vegetation, J. Hydrol., 310, 28-61, 2005.

Bruijnzeel, L. A.: Environmental impacts of (de)forestation in the humid tropics: A watershed perspective, Wallaceana, 46, 3-13, 1986.

Bruijnzeel, L.A.: (De)forestation and streamflow in the tropics: A closer look, J. Tropical Forest Sci., 1, 229-243, 1989.

Bruijnzeel, L. A.: Hydrology of Moist Tropical Forests and Effects of Conversion: A State of Knowledge Review, UNESCO, Paris, and Vrije Universiteit, Amsterdam, 226 pp., 1990.

Bruijnzeel, L. A.: Hydrology of forest plantations in the tropics, in: Management of Soil, Nutrients and Water in Tropical Plantation Forests, edited by: Nambiar, E. K. S. and Brown, A. G., ACIAR Monograph No. 43, ACIAR, Canberra, Australia, 125167, 1997.

Bruijnzeel, L. A.: Hydrological functions of tropical forests: Not seeing the soil for the trees?, Agr. Ecosyst. Environ., 104, 185228, 2004.

Bruijnzeel, L. A. and Bremmer, C. N.: Highland-Lowland Interactions in the Ganges-Brahmaputra River Basin: A Review of Published Literature. ICIMOD Occasional Paper no. 11, ICIMOD, Kathmandu, Nepal, 136 pp., 1989.

Bruijnzeel, L. A., Peña-Arancibia, J. L., and Mulligan, M.: Identifying "bright spots" of potentially enhanced stream flow after reforesting degraded land across the tropics, in: Asia-Pacific Workshop on Water and Forests - Beyond Traditional Forest Hydrology, Singh MD (Convener), Forest Research Institute, Dehradun, India, p. 41, 2013.

Burgess, S. S. O., Adams, M., Turner, N. C., Beverly, C. R., Ong, C. K., Khan, A. A. H., and Belby, T. M.: An improved heat pulse method to measure low and reverse rates of sap flow in woody plants, Tree Physiol., 21, 589-598, 2001.

Calder, I. R.: Water use of eucalypts - A review, in: Growth and Water Use of Forest Plantations, edited by: Calder, I. R., Hall, R. L., and Adlard, P. G., J. Wiley, Chichester, UK, 167-175, 1992.

Calder, I. R.: The Blue Revolution. Integrated Land and Water Resource Management (2nd Edn.), Earthscan, London, 353 pp., 2005.

Chandler, D. G.: Reversibility of forest conversion impacts on water budgets in tropical karst terrain, Forest Ecol. Manage., 224, 95103, 2006.

Chandler, D. G. and Walter, M. F.: Runoff responses among comon land uses in the uplands of Matalom, Leyte, Philippines, Trans. Am. Soc. Agr. Eng., 41, 1635-1641, 1998.

Chappell, N. A. and Lancaster, J. W.: Comparison of methodological uncertainties within permeability measurements, Hydrol. Process., 21, 2504-2514, 2007. 
Chappell, N. A., Sherlock, M., Bidin, K., Macdonald, R., Najman, Y., and Davies, G.: Runoff processes in Southeast Asia: Role of soil, regolith, and rock type, in: Forest Environments in the Mekong River Basin, edited by: Swada, H., Araki, M., Chappell, N. A., La Frankie, J. V., and Shimizu, A., Springer-Verlag: Tokyo, 3-23, 2007.

Choi, H. T. and Kim, Y. K.: Impacts of afforestation, reforestation and forest management pratices on the long-term streamflow patterns and water balance at the catchment scale in Korea, in: AsiaPacific Workshop on Water and Forests - Beyond Traditional Forest Hydrology, edited by: Singh, M. D. (Convener), Forest Research Institute, Dehradun, India, p. 44, 2013.

Colloff, M. J., Pullen, K. R., and Cunningham, S. A.: Restoration of an ecosystem function to revegetaion communities: The role of invertebrate macropores in enhancing soil water infiltration, Restor. Ecol., 18, 65-72, 2010.

Costa, M. H., Botta, A., and Cardille, J. A.: Effects of large-scale changes in land cover on the discharge of the Toscantins River, Southeastern Amazonia, J. Hydrol., 283, 206-217, 2003.

Craig Collier, J. and Zhang, G. J.: Aerosol direct forcing of the summer Indian monsoon as simulated by the NCAR CAM3, Clim. Dynam., 32, 313-332, 2009.

Deuchars, S. A., Townend, J., Aitkenhead, M. J., and Fitzpatrick, E. A.: Change in soil structure and hydraulic properties in regenerating rain forest, Soil Use Manage., 15, 183-187, 1999.

Ding, M. M., Yi, W. M., Liao, L. Y., Martens, R., and Insam, H.: Effect of afforestation on microbial biomass and activity in soils of tropical China, Soil Biol. Biochem., 24, 865-872, 1992.

Dobremez, J. F.:Le Népal - Écologie et Biogéographie. Centre National de la Recherche Scientifique, Paris, France, 356 pp., 1976.

Ellison, D., Futter, M. N., and Bishop, K.: On the forest coverwater yield debate : From demand- to supply-side thinking, Global Change Biol., 18, 806-820, doi:10.1111/j.13652486.2011.02589.x, 2011.

FAO: World Reference Base for Soil Resources (2006) First update 2007, World Soil Resources Reports 103; United Nations Food and Agriculture Organization. Rome, 115 pp., 2007.

FAO-CIFOR: Forests and Floods: Drowning in Fiction or Thriving on Facts? RAP Publication 2005/03, Forest Perspectives 2. United Nations Food and Agriculture Organization, Rome, and Center for International Forestry Research, Bogor, 30 pp., 2005.

Farley, K. A., Jobbagy, E. G., and Jackson, R. J.: Effects of afforestation on water yield: A global synthesis with implications for policy, Global Change Biol., 11, 1565-1576, 2005.

Forsyth, T. and Walker, A.: Forest Guardians, Forest Destroyers. The Politics of Environmental Knowledge in Northern Thailand. University of Washington Press, Seattle, WA, USA, 302 pp., 2008

Fritsch, J. M.: The hydrological effects of clearing tropical rainforest and of implementation of alternative land uses, Int. Assoc. Hydrol. Sci. Public., 216, 53-66, 1993.

Galudra, G. and Sirait, M.: A discourse on Dutch colonial forest policy and science in Indonesia at the beginning of the 20th century, Int. Forestry Rev., 11, 524-533, 2009.

Gash, J. H. C., Lloyd, C. R., and Lachaud, G.: Estimating sparse forest rainfall interception with an analytical model, J. Hydrol., 170, 79-86, 1995.

Gerrard, A. J. and Gardner, R. A. M.: Relationships between runoff and land degradation on non-cultivated land in the Middle Hills of Nepal, Int. J. Sustain. Develop. World Economy, 9, 59-73, 2002.

Ghimire, C. P.: Hydrological impacts of reforesting degraded pasture land in the Middle Mountain Zone, Central Nepal. PhD Dissertation, Vrije Universiteit, Amsterdam (FALW-VUA) and University of Twente (ITC-UT), Enschede, The Netherlands, 169 pp., available at: http://www.itc.nl/library/papers_2014/phd/ ghimire.pdf, 2014.

Ghimire, C. P., Bruijnzeel, L. A., Lubczynski, M. W., and Bonell, M.: Rainfall interception by natural and planted forests in the Middle Mountains of Central Nepal, J. Hydrol., 475, 270-280, 2012.

Ghimire, C. P., Bonell, M., Bruijnzeel, L. A., Coles, N. A., and Lubczynski, M. W.: Reforesting severely degraded grassland in the Lesser Himalaya of Nepal: Effects on soil hydraulic conductivity and overland flow production, J. Geophys. Res.-Earth Surf., 118, 2528-2545, 2013.

Ghimire, C. P., Bruijnzeel, L. A., Bonell, M., Coles, N., Lubczynski, M. W., and Gilmour, D.A.: The effects of sustained forest use on hillslope soil hydraulic conductivity in the Middle Mountains of Central Nepal, Ecohydrol., 7, 478-495, doi:10.1002/eco.1367, 2014a.

Ghimire, C. P., Lubczynski, M. W., Bruijnzeel, L. A., and ChavarroRincón, D.: Transpiration, canopy conductance and decoupling coefficient of two contrasting forest types in the Lesser Himalaya of Central Nepal, Agr. Forest Meteorol., 197, 76-90, 2014 b.

Giambelluca, T. W.: The hydrology of altered tropical forest, Hydrol. Process., 16, 1665-1669, 2002.

Gilmour, D. A., Bonell, M., and Cassells, D. S.: The effects of forestation on soil hydraulic properties in the Middle Hills of Nepal: A preliminary assessment, Mountain Res. Develop., 7, 239-249, 1987.

Gilmour, D. A. and Shah, R.: Enhancing livelihoods and food security from agroforestry and community forestry systems in Nepal: Synthesis paper, IUCN, Kathmandu, Nepal, 2012.

Granier, A.: Une nouvelle méthode pour la mesure du flux de sève brute dans le tronc des arbres, Ann. Sci. Forest., 42, 193-200, 1985.

Grip, H., Fritsch, J. M., and Bruijnzeel, L. A.: Soil and water impacts during forest conversion and stabilisation to new land use, in: Forests, Water and People in the Humid tropics, edited by: Bonell, M. and Bruijnzeel, L. A., Cambridge University Press, Cambridge, UK, 561-589, 2005.

Grissino-Mayer, H. D.: A manual and tutorial for the proper use of an increment borer, Tree-Ring Res., 59, 63-79, 2003.

Hamilton, L. S. and King, P. N.: Tropical Forested Watersheds: Hydrologic and Soils Response to Major Uses and Conversions, Westview Press, Boulder CO, USA, 168 pp., 1983.

Hairiah, K., Sulistyani, H., Suprayogo, D., Widianto Purnomosidhi, P., Harto Widodo, R., and Van Noordwijk. M.: Litter layer residence time in forest and coffee agroforestry systems in Sumberjaya, West Lampung, Forest Ecol. Manage., 224, 45-57, 2006.

Harding, R. J.: The modification of climate by forests, in: Growth and Water Use of Forest Plantations, edited by: Calder, I. R., Hall, R. L., and Adlard, P. G., J. Wiley and Sons, Chichester, UK, 332-346, 1992.

Hassler, S. K., Zimmermann, B., Van Breugel, M., and Hall, J. S., and Elsenbeer, H.: Recovery of saturated hydraulic conductivity 
under secondary succession on former pasture in the humid tropics, Forest Ecol. Manage., 261, 1634-1642, 2011.

Hessel, R., Gupta, M. K., Singh Dataa, P., van der Elsen, E., and Sharma, S. D.: Rainfall, soil moisture content and runoff in a small catchment in the Indian Himalayas, Int. J. Ecol. Environ. Sci., 33, 115-128, 2007.

Holwerda, F., Scatena, F. N., and Bruijnzeel, L. A.: Throughfall in a Puerto Rican lower montane rain forest: A comparison of sampling strategies, J. Hydrol., 327, 592-602, 2006.

Hrabovszky, J. P. and Miyan, K.: Population growth and land use in Nepal. "The great turnabout", Mountain Res. Develop., 7, 264$270,1987$.

HURDEC Nepal and Hobley, M.: Community forestry impact study: persistence and change. Review of 30 years of community forestry in Nepal, HURDEC, Kathmandu, Nepal, 2012.

Ilstedt, U., Malmer, A., Verbeeten, E., and Murdiyarso, D.: The effect of afforestation on water infiltration in the tropics: A systematic review and meta-analysis, Forest Ecol. Manage., 251, 45-51, 2007.

Immerzeel, W. W., Pellicciotti, F., and Bierkens, M. F. P.: Rising River flows throughout the twenty-first century in two Himalayan glacierized watersheds, Nat. Geosci., 6, 742-745, 2013.

Jackson, R. B., Jobbagy, E. G., Avissar, R., Roy, S. B., Barrett, D. J., Cook, C. W., Farley, K. A., Le Maître, D. C., McCarl, B. A., and Murray, B. C.: Trading water for carbon with biological carbon sequestration, Science, 310, 1944-1947, 2005.

Joshi, G. and Negi, G. C. S.: Quantification and valuation of forest ecosystem services in the western Himalayan region of India, International Journal of Biodiversity Science, Ecosyst. Serv. Manage., 7, 2-11, 2011.

Kaimowitz, D.: Useful myths and intractable truths: The politics of the link between forests and water in Central America, in: Forests, Water and People in the Humid Tropics, edited by: Bonell, M. and Bruijnzeel, L. A., Cambridge University Press, Cambridge, UK, 86-98, 2005.

Kallarackal, J. and Somen, C. K.: Water use by Eucalyptus tereticornis stands of differing density in southern India, Tree Physiol., 17, 195-203, 1997.

Kanae, S., Oki, T., and Musiake, K.: Impact of deforestation on regional precipitation over the Indochina Peninsula, J. Hydrometeorol., 2, 51-70, 2001.

Kelliher, F. M., Koestner, B. M. M., Hollinger, D. Y., Byers, J. N., Hunt, J. E., McSeveny, T. M., Meserth, R., Weir, P. L., and Schulze, E. D.: Evaporation, xylem sap flow, and tree transpiration in a New Zealand broad-leaved forest, Agr. Forest Meteorol., 62, 53-73, 1992.

Krishnaswamy, J., Bonell, M., Venkatesh, B., Purandara, B. K., Lele, S., Kiran, M. C., Reddy, V., Badiger, S., and Rakesh, K. $\mathrm{N}$.: The rain-runoff response of tropical humid forest ecosystems to use and reforestation in the Western Ghats of India, J. Hydrol., 472-473, 216-237, 2012.

Krishnaswamy, J., Bonell, M., Venkatesh, B., Purandara, B. K., Rakesh, K. N., Lele, S., Kiran, M. C., Reddy, V., and Badiger, S.: The groundwater recharge response and hydrologic services of tropical forest ecosystems to use and reforestation: Support for the "infiltration-evapotranspiration trade-off hypothesis", J. Hydrol., 498, 191-209, 2013.
Kumagai, T., Kanamori, H., and Yasunari, T.: Deforestationinduced reduction in rainfall, Hydrol. Process., 27, 3811-3814, 2013.

Kumar, P., Wiltshire, A., Mathison, C., Asharaf, S., Ahrens, B., Lucas-Picher, Ph., Christensen, J. H., Gobiet, A., Saeed, F., Hagemann, S., and Jacob, D.: Downscaled climate change projections with uncertainty assessment over India using a high resolution multi-model approach, Sci. Total Environ., 468-469, S1830, doi:10.1016/j.scitotenv.2013.01.051, 2013.

Lal, R.: Effects of macrofauna on soil properties in tropical ecosystems, Agric. Ecosyst. Environ., 24, 101-116, 1988.

La Marche, J. L. and Lettenmaier, D. P.: Effects of forest roads on flood flows in the Deschutes River, Washington, Earth Surf. Process. Landf., 26, 115-134, 2001.

Liu, W. J., Liu, W. Y., Lu, H. J., Duan, W. P., and Li, H. M.: Runoff generation in small catchments under a native rain forest and a rubber plantation in Xishuangbanna, southwestern China, Water Environ. J., 25, 138-147, 2009.

Lu, P., Urban, L., and Zhao, P.: Granier's thermal dissipation probe method for measuring sap flow in trees: theory and practice, Acta Botanica Sinica, 46, 631-646, 2004.

Lubczynski, M. W., Chavarro-Rincon, D. C., and Roy, J.: Novel, cyclic heat dissipation method for the correction of natural temperature gradients in sap flow measurements. Part I. Theory and application, Tree Physiol., 32, 894-912, 2012.

Madduma Bandara, C. M.: Land-use changes and tropical stream hydrology: Some observations from the upper Mahaweli basin of Sri Lanka, in: Process and Form in Geomorphology, edited by: Stoddart, D. R., Routledge, London, 175-186, 1997.

Maharjan, P. L.: The soil survey of the Jikhu Khola catchment, in: Soil Fertility and Erosion issues in the Middle Mountains of Nepal, edited by: Shah, P. B., Schreier, H., Brown, S. J., and Riley, K. W., Topographical Survey Branch, Kathmandu, and University of British Columbia, Vancouver, 195-200, 1991.

Malmer, A., Murdiyarso, D., Bruijnzeel, L. A., and Ilstedt, U.: Carbon sequestration in tropical forests and water: A critical look at the basis for commonly used generalizations, Global Change Biol., 16, 599-604, 2010.

Mathison, C., Wiltshire, A., Dimri, A. P., Falloon, P., Jacob, D., Kumar, P., Moors, E., Ridley, J., Siderius, Ch., Stoffel, M., and Yasunari, T.: Regional projections of North Indian climate for adaptation studies, Sci. Total Environ., 468-469, S4-S17, doi:10.1016/j.scitotenv.2012.04.066, 2012.

McIntyre, D. S.: Permeability measurements of soil crusts formed by raindrop impact, Soil Sci., 85, 185-189, 1958a.

McIntyre, D. S.: Soil splash and the formation of surface crusts by raindrop impact, Soil Sci., 85, 261-266, 1958b.

McKenzie, N. J., Cresswell, H. P., and Green, T. W.: Field measurement of unsaturated hydraulic conductivity using tension infiltrometers, in: Soil Physical Measurement and Interpretation for Land Evaluation, edited by: Mckenzie, N., Coughlan, K., and Cresswell, H., CSIRO Publishing, Melbourne, 119-130, 2002.

Merz, J.: Water balances, floods and sediment transport in the Hindu Kush-Himalayas. Geographica Bernensia G72, University of Bern, Bern, Switzerland, 339 pp., 2004.

Merz, J., Nakarmi, G., Shrestha, S. K., Dahal, B. M., Dangol, P. M., Dhakal, M. P., Dongol, B. S., Sharma, S., Shah, P. B., and Weingartner, R.: Water: A scarce resource in rural watersheds of 
Nepal's Middle Mountains, Mountain Res. Develop., 23, 41-49, 2003.

Molina, A., Govers, G., Vanacker, V., Poesen, J., Zeelmaekers, E., and Cisneros, F.: Runoff generation in a degraded Andean ecosystem: Interaction of vegetation cover and land use, Catena, 71, 357-370, 2007

Motzer, T., Munz, N., Anhuf, D., and Küpper, M.: Transpiration and microclimate of a tropical montane rain forest, southern Ecuador, in: Tropical Montane Cloud Forests: Science for Conservation and Management, edited by: Bruijnzeel, L. A., Scatena, F. N., and Hamilton, L.S., Cambridge University Press, Cambridge, UK, 447-455, 2010.

Nadezhdina, N., Vandegehuchte, M., and Steppe, K.: Sap flux density measurements based on the heat field deformation method, Trees - Structure and Function, 26, 1439-1448, 2012.

Nakarmi, G.: Geological mapping and its importance for construction material, water chemistry, and terrain stability in the Jikhu and Yarsa Khola catchments, in: The People and Resources Dynamics: The First Three Years (1996-1999), edited by: Allen, R., Schreier, H., Brown, S., and Shah, P. B., ICIMOD, Baoshan, Nepal, 253-261, 2000.

Ogden, F. L., Crouch, T. D., Stallard, R. F., and Hall, J. S.: Effect of land cover and use on dry season river runoff, runoff efficiency, and peak storm runoff in the seasonal tropics of Central Panama, Water Resour. Res., 49, 1-20, 2013.

Oldeman, L. R., Hakkeling, R. T. A., and Sombroek, W. G.: World Map of the Status of Human-Induced Soil Degradation: An Explanatory Note (Second Edition). International Soil Reference and Information Centre, Wageningen, The Netherlands, 1991.

Pathak, P. C., Pandey, A. N., and Singh, J. S.: Overland flow, sediment output and nutrient loss from certain forested sites in the central Himalaya, India, J. Hydrol., 71. 239-251, 1984.

Patnaik, N. and Virdi, S. S.: Field infiltration studies in Doon Valley, Irrig. Power, 19, 1003-1012, 1962.

Peña-Arancibia, J. L., Van Dijk, A. I. J. M., Guerschman, J. P., Mulligan, M., Bruijnzeel, L. A., and McVicar, T.: Using multiple lines of evidence to evaluate the hydrological response to deforestation of large catchments in the dry tropics of Queensland, Australia, J. Hydrol., 416-417, 60-71, 2012.

Perkins, K. S., Nimmo, J. R., and Medeiros, A. C.: Effects of native forest restoration on soil hydraulic properties, Auwahi, Maui, Hawaiian, Islands, Geophys. Res. Lett., 39, L05405, doi:10.1029/2012GL051120, 2012.

Perroux, K. M. and White, I.: Designs for disc permeameters, Soil Sci. Soc. America J., 52, 1205-1215, 1988.

República: Locals blame pine trees for declining water sources. República Vol. IV, No. 202 (19 November 2012), available at: www.myrebulica.com, last access: 21 November 2012.

Reynolds, W. D., Elrick, D. E., and Clothier, B. E.: The constant head well permeameter: effect of unsaturated flow, Soil Sci., 139, 172-180, 1985.

Rijsdijk, A., Bruijnzeel, L. A., and Kukuh Sutoto, C.: Runoff and sediment yield from rural roads, trails and settlements in the upper Konto catchment, East Java, Indonesia, Geomorphology, 87, 28-37, 2007.

Roa-García, M. C., Brown, S., Schreier, H., and Lavkulich, L. M.: The role of land use and soils in regulating water flow in small headwater catchments of the Andes, Water Resour. Res., 47, W05510, doi:10.1029/2010WR009582, 2011.
Schreier, H., Brown, S., and MacDonald, J. R. (Eds.): Too Little and Too Much: Water and Development in a Himalayan Watershed, Institute for Resources and Environment, University of British Columbia, Canada, 258 pp., 2006.

Scott, D. F. and Prinsloo, F. W.: Longer-term effects of pine and eucalypt plantations on streamflow, Water Resour. Res., 44, W00A08, doi:10.1029/2007WR006781, 2008.

Scott, D. F., Bruijnzeel, L. A., and Macksensen, J.: The hydrological and soil impacts of forestation in the tropics, in: Forest, Water and People in the Humid Tropics, edited by: Bonell, M. and Bruijnzeel, L. A., Cambridge University Press, Cambridge, UK, 622-650, 2005.

Shrestha, A. B., Wake, C. P., Dibb, J. E., and Mayewski, P. A.: Precipitation fluctuations in the Nepal Himalaya and its vicinity and relationship with some large scale climatological parameters, Int. J. Climatol., 20, 317-327, 2000.

Sidle, R. C. and Ziegler, A. D.: The dilemma of mountain roads, Nat. Geosci., 5, 437-438, 2012.

Sidle, R. C., Ziegler, A. D., Negishi, J. N., Nik, A. R., Siew, R., and Turkelboom, F.: Erosion processes in steep terrain - Truths, myths, and uncertainties related to forest management in Southeast Asia, Forest Ecol. Manage., 224, 199-225, 2006.

Šimůnek, J., Sejna, M., Saito, H., Sakai, M., and van Genuchten, M. T.: The HYDRUS 1D software package for simulating the one-dimensional movement of water, heat, and multiple solutes in variability-saturated media, University of California Riverside, California, 281 pp., 2008.

Singh, N. and Sundriyal, R. C.: Fuelwood, fodder consumption and deficit pattern in a Central Himalayan village, Nat. Sci., 7, 85-88, 2009.

Singh, J. S., Pandey, U., and Tiwari, A. K.: Man and forests: A Central Himalayan case study, Ambio, 13, 80-87, 1984.

Spracklen, D. V., Arnold, S. R., and Taylor, C. M.: Observations of increased tropical rainfall preceded by air passage over forests, Nature, 489, 282-286, doi:10.1038/nature11390, 2012.

Stednick, J. D.: Monitoring the effects of timber harvest on annual water yield, J. Hydrol., 176, 79-95, 1996.

Stocklin, J. and Bhattarai, K.: Geology of Kathmandu area and Central Mahabharat range, HMG/UNDP Mineral Exploration Project, Kathmandu, Nepal, 1997.

Sun, G., Zhou, G. Y., Zhang, Z. Q., Wei, X. H., McNulty, S. G., and Vose, J. M.: Potential water yield reduction due to forestation across China, J. Hydrol., 328, 548-558, 2006.

Talsma, T. and Hallam, P. M.: Hydraulic conductivity measurement of forest catchments, Aust. J. Soil Res., 18, 139-148, 1980.

Tiwari, K. R., Sitaula, B. K., Bajracharya, R. M., and Børresen, T.: Runoff and soil loss responses to rainfall, land use, terracing and management practices in the middle Mountains of Nepal, Acta Agriculture and Scandinavica, Section B - Soil Plant Sci., 59, 197-207, 2009.

Tiwari, R. K., Rai, S. P., Qazi, N., and Kumar, B.: Stream discharge analysis under different forest covers: a case study from paired microwatersheds of Garhwal Himalaya, India, Indian Forest., 137, 805-813, 2011.

Tobón, C., Bruijnzeel, L. A., Frumau, K. F. A., and Calvo-Alvarado, J. C.: Change in soil physical properties after conversion of tropical montane cloud forest to pasture in northern Costa Rica, in: Tropical Montane Cloud Forests: Science for Conservation and Management, edited by: Bruijnzeel, L. A., Scatena, F. N., and 
Hamilton, L. S., Cambridge University Press, Cambridge, UK, 502-515, 2010.

Tomasella, J. and Hodnett, M. G.: Soil hydraulic properties and van Genuchten parrameters for an oxisol under pasture in central Amazonia, in: Amazonian Deforestation and Climate, edited by: Gash, J. H. C., Nobre, C. A., Roberts, J. M., and Victoria, R. L., J. Wiley and Sons, Chichester, UK, 101-124, 1996.

Tomich, T. P., Thomas, D. E., and van Noordwijk, M.: Environmental services and land use change in Southeast Asia: From recognition to regulation or rewards?, Agr. Ecosyst. Environ., 104, 229244, 2004.

Trimble, S. W., Weirich, F. H., and Hoag, B. L.: Reforestation and the reduction of water yield on the southern Piedmont since circa 1940, Water Resour. Res., 23, 425-437, 1987.

Tyagi, J. V., Qazi, N., Rai, S. P., and Singh, M. P.: Analysis of soil moisture variation by forest cover structure in lower western Himalayas, J. Forest. Res., 24, 1-8, 2013.

Van Dijk, A. I. J. M., Peña-Arancibia, J., and Bruijnzeel, L. A.: Land cover and water yield: Inference problems when comparing catchments with mixed land cover, Hydrol. Earth Syst. Sci., 16, 3461-3473, doi:10.5194/hess-16-3461-2012, 2012.

Van Genuchten, M. T.: A closed form equation for predicting the hydraulic conductivity of unsaturated soils, Soil Sci. Soc. Am. J., 44, 892-898, 1980.

Van Noordwijk, M. and Leimona, B.: Principles for fairness and efficiency in enhancing Environmental Services in Asia: Payments, compensation, or co-Investment?, Ecol. Soc., 15, available at: http://www.ecologyandsociety.org/vol15/iss4/art17/, 2010.

Van Noordwijk, M., Tomich, T. P., and Verbist, B.: Negotiation support models for integrated natural resource management in tropical forest margins, Conserv. Ecol., 5, 21-42, 2001.

Varikoden, H., Revadekar, J. V., Choudhary, Y., and Preethi, B.: Droughts of Indian summer monsoon associated with El Niño and Non-El Niño years, Int. J. Climatol., doi:10.1002/joc.4097, in press, 2014.

Vertessy, R. A., Watson, F. G. R., and O'Sullivan, S. K.: Factors determining relations between stand age and catchment water yield in mountain ash forests, Forest Ecol. Manage., 143, 13-26, 2001.

Wallace, J. S., Young, A., and Ong, C. K.: The potential of agroforestry for sustainable land and water management, in: Forests, Water and People in the Humid tropics, edited by: Bonell, M. and Bruijnzeel, L. A., Cambridge University Press, Cambridge, UK, 652-670, 2005.

Waterloo, M. J., Bruijnzeel, L. A., Vugts, H. F., and Rawaqa, T. T.: Evaporation from Pinus caribaea plantations on former grassland soils under maritime tropical conditions, Water Resour. Res., 35, 2133-2144, 1999.

Wester, R. G. C.: Feasibility of assessing water scarcity with $3 R$ techniques, in the Salyan district in the Middle Mountains of western Nepal, M.Sc. Thesis, VU University, Amsterdam, The Netherlands, 148 pp., 2013.
Wiersum, K. F.: Surface erosion under various tropical agroforestry systems, in: Symposium on Effects ofForest Land Use on Erosion and Slope Stability, edited by: O'Loughlin, C. L. and Pearce, A. J., East-West Center, Honolulu, Hawai'i, 231-239, 1984.

Wiersum, K. F.: Effects of various vegetation layers in an Acacia auriculiformis forest plantation on surface erosion in Java, Indonesia, in: Soil Erosion and Conservation, edited by: El-Swaify, S., Moldenhauer, W. C., and Lo, A., Soil Conservation Society of America: Ankeny, Wisconsin, 79-89, 1985.

Wohl, E., Barros, A., Brunsell, N., Chappell, N. A., Coe, M., Giambelluca, T. W., Goldsmith, S., Harmon, R., Hendrickx, J. M. H., Juvik, J. O., McDonnell, J. J., and Ogden, F. L.: The hydrology of the humid tropics, Nat. Clim. Change, 2, 655-662, 2012.

Yadav, R. K.: Role of equatorial central Pacific and northwest of North Atlantic 2-metre surface temperatures in modulating Indian summer monsoon variability, Clim. Dynam., 32, 549-563, 2009.

Zhang, B., Yang, Y. S., and Zepp, H.: Effect of vegetation restoration on soil and water erosion and nutrient losses of a severely eroded clayey Plinthudult in southeastern China, Catena, 57, 7790, 2004.

Zhang, L., Hickel, K., Dawes, W. R., Chiew, F. H. S., Western, A. W., and Briggs, P. R.: A rational function approach for estimating mean annual evapotranspiration, Water Resour. Res., 40, W02502, doi:10.1029/2003WR002710, 2004.

Zhou, G. Y., Morris, J. D., Yan, J. H., Yu, Z. Y., and Peng, S. L.: Hydrological impacts of reafforestation with eucalypts and indigenous species: A case study in southern China, Forest Ecol. Manage., 16, 209-222, 2002.

Zhou, G. Y., Wei, X., Luo, Y., Zhang, M., Li, Y., Qiao, Y., Liu, H., and Wang, C.: Forest recovery and river discharge at the regional scale of Guangdong Province, China, Water Resour. Res., 46, W09503, doi:10.1029/2009WR008829, 2010.

Ziegler, A. D. and Giambelluca, T. W.: Importance of rural roads as source areas for runoff in mountainous areas of northern Thailand, J. Hydrol., 196, 204-229, 1997.

Ziegler, A. D., Ziegler, A. D., Giambelluca, T. W., Sutherland, R. A., Nullet, M. A., Yarnasarn, S., Pinthong, J., Preechapanya, P., and Jaiaree, S.: Toward understanding the cumulative impacts of roads in upland agricultural watersheds of Northern Thailand, Agr. Ecosyst. Environ., 104, 145-158, 2004.

Ziegler, A. D., Negishi, J. N., Sidle, R. C., Gorni, T., Noguchi, S., and Rahim Nik, A.: Persistence of road runoff generation in a logged catchment in Peninsular Malaysia, Earth Surf. Process. Landf., 32, 1947-1970, 2007.

Zimmermann, B., Elsenbeer, H., and De Moraes, J. M.: The influence of land-use changes on soil hydraulic properties: Implications for runoff generation, Forest Ecol. Manage., 222, 29-38, 2006. 